\title{
Multipotential Alkaline Protease From a Novel Pyxidicoccus sp. 252: Ecofriendly Replacement to Various Chemical Processes
}

\author{
Sonia Sharma ${ }^{1}$, Shiv Kumar ${ }^{1}$, Rajinder Kaur ${ }^{2}$ and Ramandeep Kaur ${ }^{3 *}$ \\ 'Department of Biotechnology, Guru Nanak Dev University, Amritsar, India, ${ }^{2}$ Department of Botanical and Environmental \\ Sciences, Guru Nanak Dev University, Amritsar, India, ${ }^{3}$ Department Cum National Centre for Human Genome Studies \\ and Research, Panjab University, Chandigarh, India
}

\section{OPEN ACCESS}

Edited by:

Byong-Hun Jeon,

Hanyang University, South Korea

Reviewed by:

Sunil More,

Dayananda Sagar University, India

Sedky Hassan,

New Valley University, Egypt

*Correspondence:

Ramandeep Kaur

rkaur.biotech@gmail.com

Specialty section:

This article was submitted to

Microbiotechnology,

a section of the journal

Frontiers in Microbiology

Received: 09 June 2021 Accepted: 26 August 2021

Published: 11 October 2021

Citation:

Sharma S, Kumar S, Kaur R and Kaur R (2021) Multipotential Alkaline Protease From a Novel Pyxidicoccus sp. 252: Ecofriendly Replacement

to Various Chemical Processes.

Front. Microbiol. 12:722719.

doi: 10.3389/fmicb.2021.722719
A newly isolated alkaline protease-producing myxobacterium was isolated from soil. The strain was identified as Pyxidicoccus sp. S252 on the basis of 16S rRNA sequence analysis. The extracellular alkaline proteases produced by isolate S252 (PyCP) was optimally active in the $\mathrm{pH}$ range of $11.0-12.0$ and temperature range of $40-50^{\circ} \mathrm{C}$ The zymogram of PyCP showed six caseinolytic protease bands. The proteases were stable in the $\mathrm{pH}$ range of $8.0-10.0$ and temperature range of $40-50^{\circ} \mathrm{C}$. The activity of PyCP was enhanced in the presence of $\mathrm{Na}^{+}, \mathrm{Mg}^{2+}, \mathrm{Cu}^{2+}$, Tween-20, and hydrogen peroxide $\left(\mathrm{H}_{2} \mathrm{O}_{2}\right)$ (hydrogen peroxide), whereas in Triton X-100, glycerol, ethylenediaminetetraacetic acid (EDTA), and $\mathrm{Co}^{2+}$, it was stable. PyCP showed a potential in various applications. The addition of PyCP in the commercial detergent enhanced the wash performance of the detergent by efficiently removing the stains of tomato ketchup and coffee. PyCP efficiently hydrolyzed the gelatin layer on X-ray film to release the embedded silver. PyCP also showed potent dehairing of goat skin and also efficiently deproteinized sea shell waste indicating its application in chitin extraction. Thus, the results of the present study indicate that Pyxidicoccus sp. S252 proteases have the potential to be used as an ecofriendly replacement of chemicals in several industrial processes.

\footnotetext{
Keywords: Pyxidicoccus sp., myxobacteria, alkaline proteases, surfactant and oxidant stable proteases, chitin extraction, bioextraction
}

\section{INTRODUCTION}

Proteases are hydrolytic enzymes that are capable of catalyzing the hydrolysis of peptide bonds and thus degrade proteins into simpler peptides. Proteases can be classified based on the site of action, substrate specificity, similarity to studied enzymes, amino acids at the active site, and $\mathrm{pH}$ optima (Banerjee and Ray, 2017). On the basis of the site of action, they are categorized into endo- or exo-enzymes, and based on the amino acids at the active site, they are classified as serine, cysteine, aspartic, and metallo proteases. Based on the $\mathrm{pH}$ optima, they are classified as acidic, neutral, and alkaline proteases (Rao et al., 1998). A comprehensive compilation of proteases can be accessed in the MEROPS peptidase database (Rawlings et al., 2018).

Proteases are ubiquitous in prokaryotes and eukaryotes, where they play important roles in physiology of the host organisms. Proteases are also commercially important and command 
the largest share (60\%) of the enzymes used in industrial processes. Alkaline proteases account for 35\% of these proteases and are used in food, leather, silk, laundry, tannery, cosmetics, and pharmaceutical industries (Ramkumar et al., 2018). Furthermore, microorganisms are the preferred source for industrial enzymes because they are easy to maintain and cultivate and are amenable to genetic manipulations enabling higher yield of the enzymes (Asgher et al., 2018; Zhou et al., 2018; Yu et al., 2019).

The enzymes are environmentally safe substitutes for hazardous chemicals in industrial processes (Razzaq et al., 2019). The enzymes for industrial use are produced in bulk and can be employed as crude preparations to make the process more cost effective. The use of crude proteases suffices for most applications such as, in detergents, bioactive protein hydrolysate preparation, bioextraction of chitin from shrimp shells, hide dehairing, and silver recovery from X-ray film (Cavello et al., 2013; Paul et al., 2014; Hammami et al., 2017, 2018; Murthy et al., 2018). The need to resort to the expensive and time-consuming process of purification of proteases is limited to their use in pharmaceutical and medical applications (Banerjee and Ray, 2017). A prerequisite for an enzyme to be successfully adopted in industries is that it should have the ability to withstand harsh process conditions viz. temperature, $\mathrm{pH}$, and presence of inhibitors. The diversity of microbes inhabiting the planet enables the discovery of enzymes with the desirable industrial features.

Myxobacteria are Gram-negative, unicellular, non-pathogenic $\delta$-proteobacteria, and they inhabit soil, decaying plant material, bark of trees, herbivore dung, and the marine environment (Reichenbach and Dworkin, 1992; Dawid, 2000; lizuka et al., 2013; Garcia et al., 2014). They are generally considered mesophiles $\left(6-38^{\circ} \mathrm{C}\right)$ and grow in wide $\mathrm{pH}$ range of 5-9. Myxobacteria show cooperative behavior, as is evident from the swarming of cells which is the result of cell-cell communication and cooperation among the cells (Dawid, 2000). Myxobacteria practice group predation and produce a wide variety of hydrolytic enzymes to lyse the prey cells for acquiring nutrients (MuñozDorado et al., 2016). To sustain in the competitive environmental niche, it is expected that myxobacteria would secrete robust and efficient proteases which can withstand harsh environmental conditions. With the growing emphasis of industrial processes toward cleaner technologies, the attention is focused on the discovery of robust enzymes with unique properties. Though myxobacteria have been extensively explored for bioactive secondary metabolites, there are very scant reports of the studies on the industrially important enzymes from myxobacteria. Recently, prolyl oligopeptidase from Myxococcus xanthus that had shown promise in the preparation of bioactive peptides by gluten hydrolysis was expressed in Escherichia coli (Shan et al., 2004; Kocadag Kocazorbaz and Zihnioglu, 2017). A novel milk extracellular clotting protease with utility in cheese industry was characterized from M. xanthus strain 422 (Poza et al., 2003).

In view of the emphasis on making the industrial processes ecologically sustainable, the present study aimed to determine the biotechnological potential of proteases produced by the newly isolated strain of myxobacterium, Pyxidicoccus sp. S252. The application of the extracellular proteases produced by isolate S252
(PyCP) as detergent additive, in hydrolysis of gelatin for silver recovery from used X-ray films and animal hide dehairing was evaluated. To the best of our knowledge, this is the first report on the characterization and potential applications of alkaline proteases from a myxobacterium of the genus Pyxidicoccus.

\section{MATERIALS AND METHODS}

\section{Isolation and Identification of S252}

Myxobacteria were isolated as described in Kumar et al. (2017). Briefly, soil samples were placed on E. coli paste spread on water calcium chloride clerigel (WCX clerigel; $0.1 \% \mathrm{CaCl}_{2} \cdot 2 \mathrm{H}_{2} \mathrm{O}$, $20 \mathrm{mM}$ HEPES buffer, $0.8 \%$ clerigel, and $50 \mu \mathrm{g} / \mathrm{ml}$ cycloheximide; $\mathrm{pH}$ 7.2). The strains were purified by picking cells from the edge of the swarm that emerged from soil sample and were grown on casitone yeast (CY) agar medium $(0.3 \%$ casitone, $0.1 \%$ yeast extract, $0.1 \% \mathrm{CaCl}_{2} \cdot 2 \mathrm{H}_{2} \mathrm{O}$, and $1.5 \%$ agar; $\mathrm{pH}$ 7.2) for growth. The isolated bacterial strains were subjected to Gram staining. The ability of the myxobacterial strains to produce extracellular protease was tested on skim milk agar (1\% skim milk, $0.1 \%$ $\mathrm{CaCl}_{2} \cdot 2 \mathrm{H}_{2} \mathrm{O}, 2 \%$ agar, $\mathrm{pH} 11$ ).

Genomic DNA was isolated from the cells scrapped from freshly streaked and overnight incubated culture plates using genomic DNA isolation kit (RBC, Taiwan). The genomic DNA was used as template to amplify $16 \mathrm{~S}$ rRNA gene using the universal bacterial forward primer $8 \mathrm{~F}\left(5^{\prime}\right.$-AGA GTT TGA TCC TGG CTC AG-3') and reverse primer 1492R (5'-GGT TAC CTT GTT ACG ACT T-3'). PCR reaction mixture contained $1 \times$ Taq reaction buffer, $0.2 \mu \mathrm{M}$ each primer, $200 \mu \mathrm{M}$ each dNTP, $30 \mathrm{ng}$ genomic DNA, and 1.5 U Taq DNA polymerase. PCR amplification was carried out by denaturation for $2 \mathrm{~min}$ at $95^{\circ} \mathrm{C}$ followed by 30 cycles of denaturation at $95^{\circ} \mathrm{C}$ for $45 \mathrm{~s}$, annealing at $45^{\circ} \mathrm{C}$ for $45 \mathrm{~s}$, extension at $72^{\circ} \mathrm{C}$ for $1 \mathrm{~min}$, and a final extension step at $72^{\circ} \mathrm{C}$ for $10 \mathrm{~min}$. The amplicon of $16 \mathrm{~S} \mathrm{rDNA}$ was purified from agarose gel using Gel/PCR DNA Kit (RBC, Taiwan) and sequenced at Bioserve Biotechnologies Pvt., Ltd., Hyderabad, India. The sequence was submitted to GenBank ${ }^{1}$. The isolated strains were identified on the basis of $16 \mathrm{~S}$ rRNA gene sequence using the EzTaxon server ${ }^{2}$. Phylogenetic tree was constructed using Mega 6.06 software package (Tamura et al., 2013).

\section{Protease Production and Assay}

Isolate S252 was grown in $\mathrm{CY}$ broth at $30^{\circ} \mathrm{C}$ for 5 days with agitation at $180 \mathrm{rpm}$. The cell-free culture supernatant (CS) was harvested by centrifugation at 8,000 rpm for $15 \mathrm{~min}$ and was used as enzyme (PyCP) for further characterization.

Proteases produced by isolate S252 was assayed using 1\% casein as a substrate in $0.05 \mathrm{M} \mathrm{KCl}-\mathrm{NaOH}$ buffer $(\mathrm{pH} 12)$. The substrate and enzyme were taken in 1:1 ratio and incubated at $40^{\circ} \mathrm{C}$ for $1 \mathrm{~h}$. The reaction was stopped by adding twice the reaction volume of $10 \%$ trichloroacetic acid (TCA) followed by incubation at $37^{\circ} \mathrm{C}$ for $30 \mathrm{~min}$. The reaction mix was centrifuged at $10,000 \mathrm{rpm}$ for $10 \mathrm{~min}$ and to $500 \mu \mathrm{l}$ supernatant, $2.5 \mathrm{ml}$ of

\footnotetext{
${ }^{1}$ www.ncbi.nlm.nih.gov/genbank/

${ }^{2}$ http://www.ezbiocloud.net/eztaxon/identify
} 
0.4 M sodium carbonate was added followed by $250 \mu \mathrm{l}$ of $1 \mathrm{~N}$ Folin-Ciocalteu's phenol reagent (Meyers and Ahearn, 1977). The reaction was developed at $37^{\circ} \mathrm{C}$ for $30 \mathrm{~min}$, and absorbance was measured at $660 \mathrm{~nm}$. One unit of protease activity was defined as the amount of enzyme necessary for the release of $1 \mu \mathrm{g}$ of tyrosine $/ \mathrm{min} / \mathrm{ml}$ under standard conditions. Tyrosine standard curve was generated using L-tyrosine $(2-200 \mu \mathrm{g} / \mathrm{ml})$.

\section{Sodium Dodecyl Sulphate-PAGE and Zymography}

Molecular weight of the extracellular proteases was estimated using 10\% sodium dodecyl sulphate (SDS)-PAGE (Laemmli, 1970). The protein bands were visualized by staining with Blue silver stain (Candiano et al., 2004).

The zymogram analysis of the PyCP was performed according to Heussen and Dowdle (1980) with minor modifications. SDSPAGE was performed by incorporating $0.01 \%$ casein in the gel. After electrophoresis, the gel was soaked in 1\% Triton X-100 for $1 \mathrm{~h}$, washed in water, and incubated overnight in $0.1 \mathrm{M}$ $\mathrm{KCl}-\mathrm{NaOH}$ buffer ( $\mathrm{pH}$ 12). The zone of clearance was observed around the active protease bands.

\section{Characterization of Alkaline Protease Effect of $\mathrm{pH}$ on Activity and Stability of Proteases Produced by Isolate $\mathrm{S} 252$}

The effect of $\mathrm{pH}$ on $\mathrm{PyCP}$ was investigated at $\mathrm{pH}$ ranging from 8.0 to 13.0 . The substrate, $1 \%$ casein, prepared in different buffer systems, i.e., phosphate buffer ( $\mathrm{pH} 7)$, Tris- $\mathrm{HCl}(\mathrm{pH} 8)$, glycine$\mathrm{NaOH}$ ( $\mathrm{pH} 9$ and 10), sodium bicarbonate buffer ( $\mathrm{pH} 11$ ), and $\mathrm{KCl}-\mathrm{NaOH}$ buffer ( $\mathrm{pH} 12$ to 13 ) was used for the enzyme assay.

The stability of the enzymes was investigated by preincubating PyCP in buffers of $\mathrm{pH} 4.0-12.0$ [sodium acetate buffer ( $\mathrm{pH} 4-5)$, phosphate buffer ( $\mathrm{pH} 6-7)]$ for $16 \mathrm{~h}$ at $4^{\circ} \mathrm{C}$ or in the buffers of $\mathrm{pH} 7-12$ for $1 \mathrm{~h}$ at $40^{\circ} \mathrm{C}$ followed by determination of residual activity by protease assay.

\section{Effect of Temperature on Activity and Stability of Proteases Produced by Isolate S252}

The effect of temperature on the activity of PyCP was assessed by carrying out the reaction at $10-70^{\circ} \mathrm{C}$ for $1 \mathrm{~h}$ at optimum $\mathrm{pH}$. The thermostability was determined by pre-incubating PyCP from 40 to $80^{\circ} \mathrm{C}$ for different time duration $(15,30,45,60$, 90 , and $120 \mathrm{~min}$ ), and residual activity was measured using standard assay conditions. The enzyme without heat treatment was considered control (100\% activity).

\section{Effect of Metal lons}

Proteases produced by isolate S252 was pre-incubated with $\mathrm{Cu}^{2+}$, $\mathrm{Ca}^{2+}, \mathrm{Mg}^{2+}, \mathrm{Zn}^{2+}, \mathrm{Co}^{2+}, \mathrm{Ni}^{2+}, \mathrm{Na}^{+}$, and $\mathrm{Ag}^{+}$at different concentrations of 1,2 , and $5 \mathrm{mM}$ for $60 \mathrm{~min}$ at $40^{\circ} \mathrm{C}$, and residual activity was determined under standard assay conditions. The activity of the enzyme without the added metal ions was considered control (100\% activity).

\section{Effect of Inhibitors}

Proteases produced by isolate S252 was pre-incubated for $60 \mathrm{~min}$ at $40^{\circ} \mathrm{C}$ in $1 \mathrm{mM}, 2.5 \mathrm{mM}$ of ethylenediaminetetraacetic acid (EDTA), phenylmethylsulfonyl fluoride (PMSF), aprotonin, and $10 \mathrm{mM}$ of $\beta$-mercaptoethanol $(\beta-\mathrm{ME})$, and the residual activity was measured under standard assay conditions. The reaction mix without inhibitor was used as control (100\% activity).

\section{Effect of Surfactants and Commercial Detergents}

The effect of surfactants on PyCP was assessed using 0.1, 0.5, and $1 \%(w / v)$ sodium dodecyl sulfate (SDS) and $1,2.5$, and $5 \%(v / v)$ Triton X-100 and Tween-20. The effect of commercial solid detergents $(0.7 \%, w / v)$; Surf excel, Ariel, Tide, Vanish Oxi Action, and liquid detergent (1:100) Ezee on PyCP was examined. The constituent enzymes in these detergents were inactivated by boiling the detergent solution for $2 \mathrm{~h}$. PyCP was pre-incubated in the respective surfactant or detergent for $1 \mathrm{~h}$ at $40^{\circ} \mathrm{C}$, and the residual activity was determined using Folin-Ciocalteu's phenol protease assay. The residual activity of PyCP without detergent incubated at $40^{\circ} \mathrm{C}$ for $1 \mathrm{~h}$ was considered control (100\% activity).

\section{Effect of Organic Solvents and Hydrogen Peroxide}

Proteases produced by isolate S252 was pre-incubated with organic solvents (25\%) of methanol, ethanol, isopropanol, acetone, butanol, chloroform, formaldehyde, and formamide for $1 \mathrm{~h}$ at $40^{\circ} \mathrm{C}$ followed by protease assay under standard assay conditions. PyCP was incubated with hydrogen peroxide $\left(\mathrm{H}_{2} \mathrm{O}_{2}\right)$ $(1,2.5$, and $5 \%)$ for $40^{\circ} \mathrm{C}$ for $1 \mathrm{~h}$, and the residual activity was determined using Folin-Ciocalteu's phenol protease assay. The activity of the enzyme without the added components incubated at $40^{\circ} \mathrm{C}$ for $1 \mathrm{~h}$ was considered $100 \%$.

\section{Substrate Specificity}

To examine the substrate specificity of PyCP, the enzyme was assayed using (1\%) casein, gelatin, and bovine serum albumin (BSA) as substrates. PyCP was incubated at the optimum temperature and $\mathrm{pH}$ with different substrates for $1 \mathrm{~h}$ to determine the relative protease activity.

\section{Performance Evaluation of Proteases Produced by Isolate S252 \\ Washing Performance Test}

Clean cotton cloth pieces (approximately $3 \mathrm{~cm} \times 4 \mathrm{~cm}$ ) were stained with tomato ketchup, coffee, and human blood. After drying, the stained cloth pieces were washed with the commercial detergent Vanish $(7 \mathrm{mg} / \mathrm{ml})$, heat-treated Vanish (in boiling water for $60 \mathrm{~min}$ to inactivate constituent enzymes), inactivated Vanish supplemented with PyCP (100 U/ml) and water. Cloth pieces washed with water and inactivated Vanish served as negative control. Washing was carried out in tubes for $60 \mathrm{~min}$ at $40^{\circ} \mathrm{C}$, followed by washing with water and drying. Washing performance was evaluated by visual observation and intensity analysis using Image J software. The percentage stain removal (StR\%) was calculated as:

$$
\text { Stain removal }(\mathrm{StR} \%)=\triangle W / \triangle W_{\circ} * 100
$$

where $\Delta W$ is the measure of color intensity difference between washed and unwashed cloth and $\Delta W_{\circ}$ is the difference in the color intensity between clean cloth and the cloth before washing (Hammami et al., 2018). 


\section{Gelatin Hydrolysis From Waste X-Ray Films}

Waste X-ray films were washed with water, wiped with ethanol, and dried at $37^{\circ} \mathrm{C}$. The film was cut into pieces, and $900 \mathrm{mg}$ film (pieces) was incubated with $100 \mathrm{U} / \mathrm{ml}$ PyCP in Tris-Cl buffer $\mathrm{pH} 8$ and $\mathrm{KCl}-\mathrm{NaOH}$ buffer $\mathrm{pH} 12$ with continuous shaking at $40^{\circ} \mathrm{C}$. The film incubated only in buffers serves as control. The progress of hydrolysis was assessed by measuring the turbidity of the reaction mix at $660 \mathrm{~nm}$ till constant turbidity value was observed. The films were also visually examined after complete hydrolysis (Cavello et al., 2013).

\section{Dehairing of Goat Skin}

Dehairing property of proteases from PyCP was studied using goat skin pieces $\left(3 \mathrm{~cm}^{2}\right)$. Goat skin pieces were washed with water to remove extraneous matter and incubated with $200 \mathrm{U} / \mathrm{ml}$ of $\mathrm{PyCP}$ at $40^{\circ} \mathrm{C}$ for $24 \mathrm{~h}$ with continuous shaking at $150 \mathrm{rpm}$. Skin pieces incubated with CY broth under same conditions were used as control. After incubation, the skin pieces were dehaired by rubbing and washing in flowing water.

\section{Bioextraction of Chitin From Shrimp and Crab Shell}

To study the deproteinization of shrimp/crab shells by the alkaline protease, $1 \mathrm{~g}$ of shrimp and crab shells washed with water and ground to small particles using pestle and mortar, were treated with $\mathrm{PyCP}$ at $40^{\circ} \mathrm{C}$. The enzyme was inactivated by heating the reaction mixture at $65^{\circ} \mathrm{C}$ for $1 \mathrm{~h}$. Subsequently, the shells were washed with distilled water and dried overnight at $50^{\circ} \mathrm{C}$. The protein content in the shells was analyzed before and after protease treatment using (FLASH 2000) CHN Elemental Analyzer, Thermo Scientific, United States (CIL Panjab University, Chandigarh, India) to determine the extent of deproteinization. Deproteinization percentage (DP\%) was calculated using 6.25 as nitrogen-to-protein conversion factor (Finke, 2013) using the following equation as described by Rao et al. (2000).

$$
\mathrm{DP} \%=\frac{\mathrm{Pc} * C-\mathrm{Pt} * T}{\mathrm{Pc} * C} * 100
$$

where, Pc and Pt are the protein concentrations (\%) before and after hydrolysis, while $C$ and $T$ are the mass in grams of the original sample and hydrolyzed residue on a dry weight basis, respectively. Rate of deproteinization at $\mathrm{pH} 8$ and 12 was also determined by evaluating the protein content in the hydrolysate at different time points using Bradford protein estimation assay.

\section{Fourier Transform Infrared Spectroscopy}

Fourier transform infrared spectroscopy (FTIR) of chitin was determined using Perkin Elmer Spectrum RX-IFTIR, Canada, spectrometer facility at Sophisticated Analytical Instrumentation Facility (SAIF) at Panjab University Chandigarh, India. The sample was prepared as $\mathrm{KBr}$ pellet and processed at room temperature. Pellets were scanned at room temperature $\left(25^{\circ} \mathrm{C}\right)$ in the range of 4,000 to $250 \mathrm{~cm}^{-1}$ with resolution of $1 \mathrm{~cm}^{-1}$ (Hamdi et al., 2017).

\section{Scanning Electron Microscopy Analysis}

The surface characteristics of the deproteinized shrimp/crab shell samples were observed under scanning electron microscope
(SEM) JSM-6100 Jeol, Japan at 50×, 250×, 1,000× and 1,500× magnifications. The samples were fixed on a sample holder, dried, and sputter-coated gold. Surface regularity was observed and compared for the test and control samples to deduce the effect of deproteinization on shrimp/crab shells.

\section{Statistical Analysis}

All experiments were carried out in triplicate, and data are presented as mean \pm standard error. Student's $t$-test was used to assess the significance of data.

\section{RESULTS}

\section{Identification of Protease-Producing Myxobacterium}

The newly isolated strains of myxobacteria (S236, S244, S250, and S252) along with the previously reported strains were identified as protease producers based on the zone of clearance on skim milk agar medium at pH 11.0 (Kumar et al., 2017). All the tested myxobacterial strains produced extracellular proteases. Based on the highest ratio of zone of clearance/colony diameter, strain S252 was selected for further studies (Table 1).

Isolate S252 is a Gram-negative, swarming bacterium with the ability to produce fruiting bodies (Figures 1A,B). Isolate S252 was identified on the basis of 16S rRNA gene sequence (GenBank accession No. KT983642) using EzTaxon and was found closely related to Pyxidicoccus fallax DSM $14698^{\mathrm{T}}$ with $99.57 \%$ sequence similarity. The phylogenetic relationship between Pyxidicoccus sp. S252 and other myxobacteria in the order Myxococcales is given in Figure 1C.

\section{Time Course of Protease Production and Zymography}

The optimum temperature of the growth of Pyxidicoccus sp. S252 is $30^{\circ} \mathrm{C}$. A typical time course of the production of protease

TABLE 1 | Protease activity of different isolates.

\begin{tabular}{|c|c|c|}
\hline SNo. & Isolates Id (GenBank accession no.) & $\mathrm{Z} / \mathrm{C}$ ratio \\
\hline 1 & S104 (JX316830) & 1.89 \\
\hline 2 & S145 (JX316838) & 1.43 \\
\hline 3 & S172 (KJ152124) & 2.33 \\
\hline 4 & S199 (KM25773) & 2.38 \\
\hline 5 & S213 (KM257735) & 1.2 \\
\hline 6 & S223 (KP178626) & 2.29 \\
\hline 7 & S225 (KM978082) & 2 \\
\hline 8 & S229 (KM978086) & 1.72 \\
\hline 9 & S233 (KM978088) & 2.29 \\
\hline 10 & S236 (KT983630) & 1.67 \\
\hline 11 & S244 (KT983635) & 1.54 \\
\hline 12 & S252 (KT983642) & 3.67 \\
\hline 13 & S250 (KT983640) & 2.0 \\
\hline
\end{tabular}


A

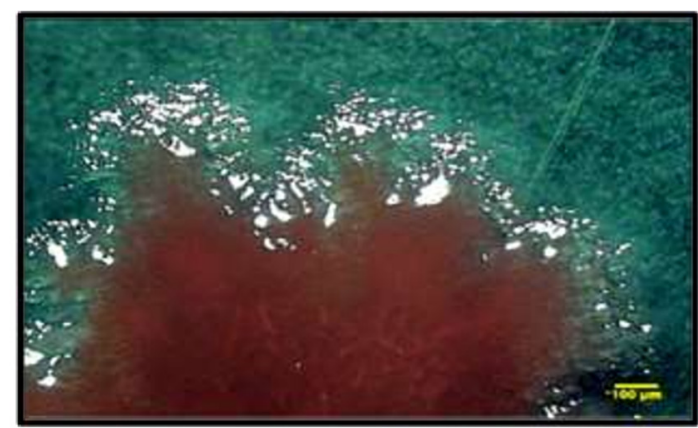

B

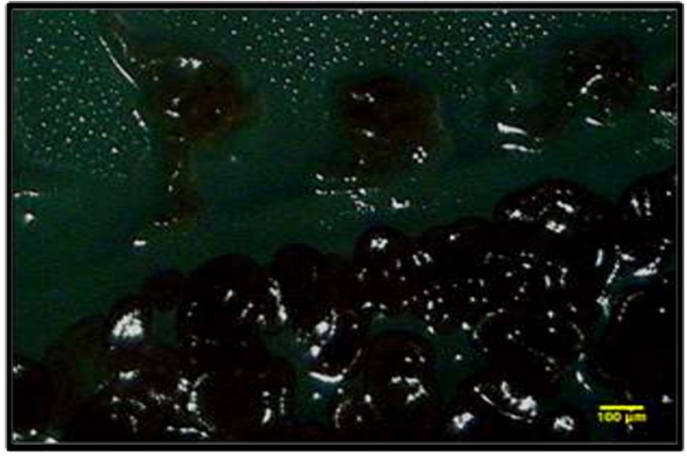

c

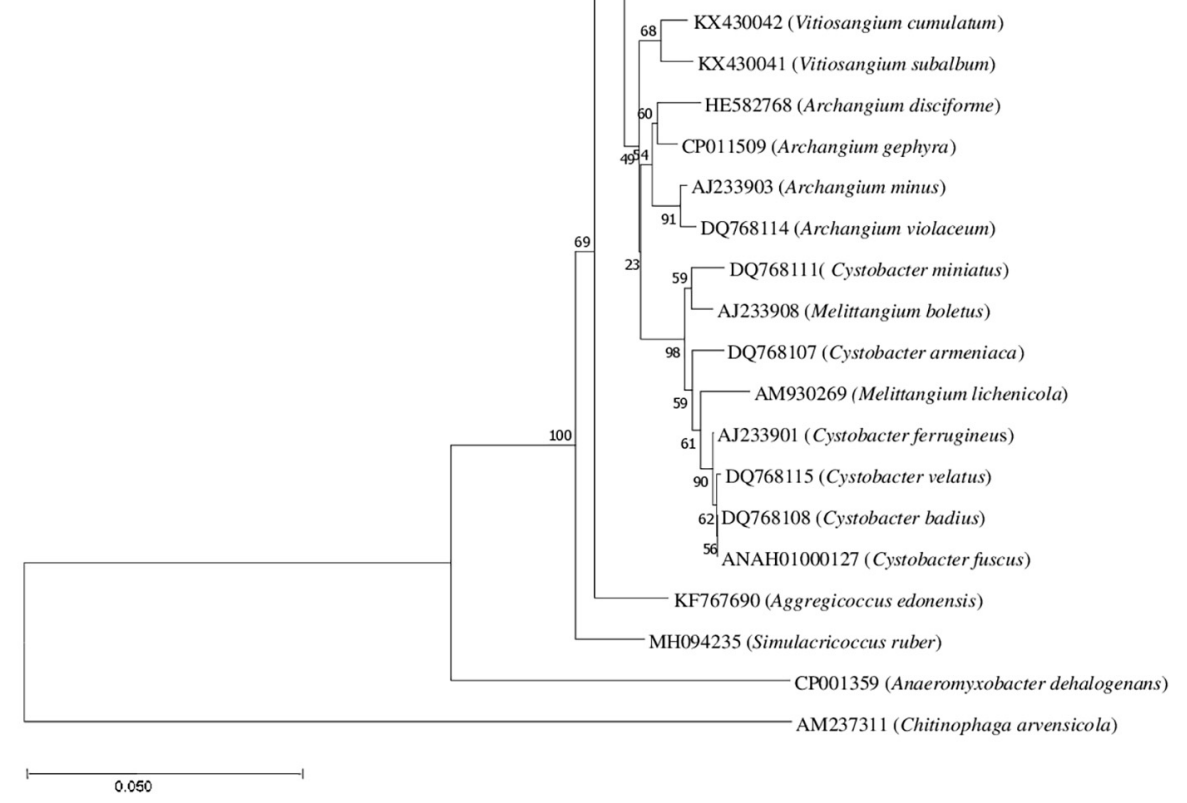

FIGURE 1 | (A) Swarm morphology (B) fruiting bodies of strain S252 under stereomicroscope. (C) Phylogenetic tree based on 16S rDNA gene sequence of Pyxidicoccus sp. S252 (blue color text) constructed using neighbor-joining method aligned with the closest type strains.

by Pyxidicoccus sp. S252 at the optimum growth temperature in CY broth is shown in Figure 2A. The extracellular protease production could be detected after $48 \mathrm{~h}$ of inoculation which reached a maximum $(3000 \mathrm{U} / \mathrm{ml})$ after $120 \mathrm{~h}$ of incubation, and the maximum activity was retained till $144 \mathrm{~h}$. SDS-PAGE and zymogram of the extracellular enzyme revealed six proteases with apparent molecular mass ranging from 15 to $50 \mathrm{kDa}$ (Figures 2B,C).

\section{Biochemical Characterization of} Proteases (Proteases Produced by Isolate S252) From Pyxidicoccus sp. S252 Effect of pH on the Activity and Stability of Proteases Produced by Isolate S252

Proteases produced by isolate S252 was highly active in the broad range of $\mathrm{pH} 8.0-12.0$ with maximum activity at $\mathrm{pH} 12.0$ 

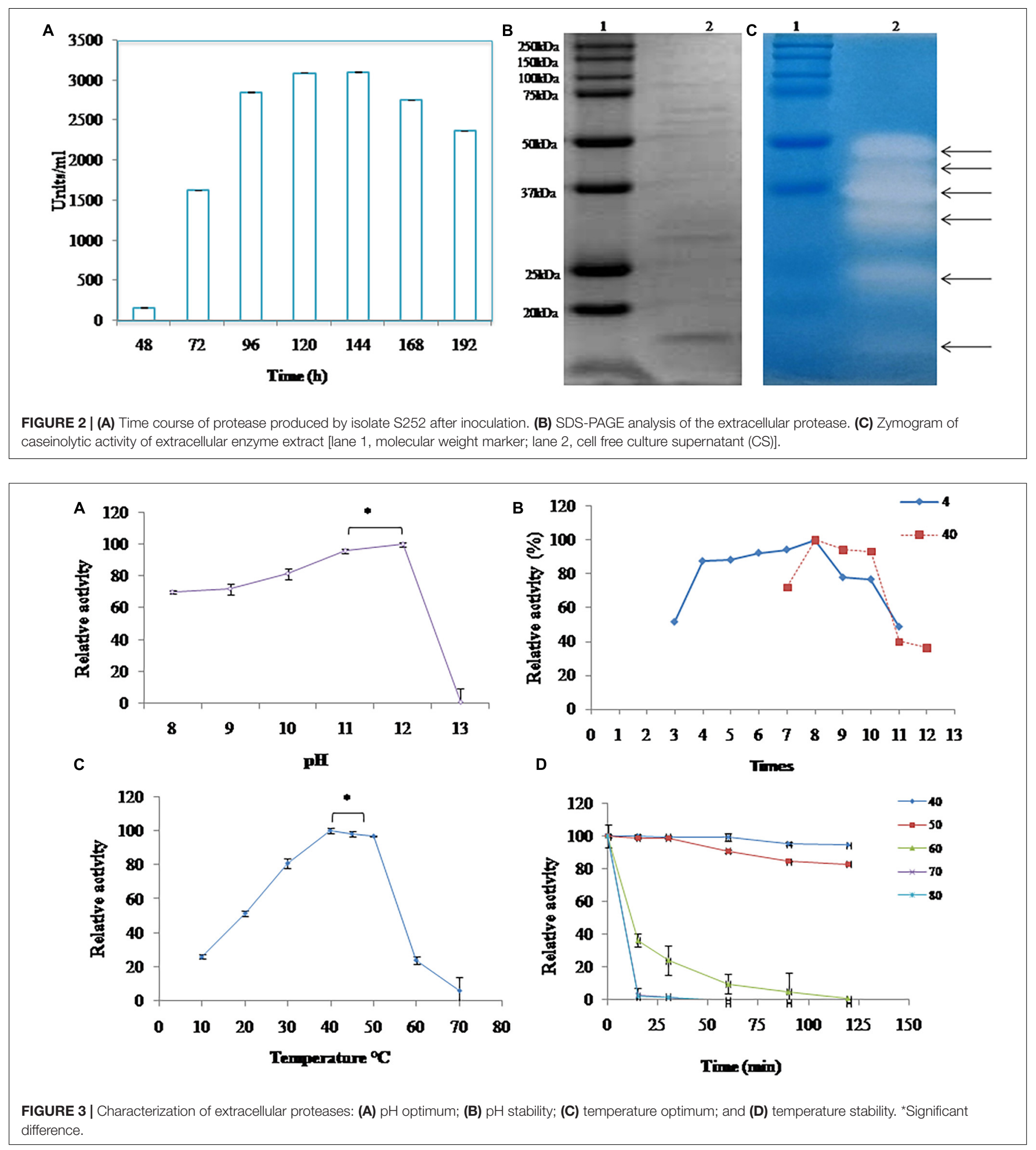

(Figure 3A). At pH 9, 10, and 11, relative activity of 72, 82, and $96 \%$ was observed, respectively; whereas at $\mathrm{pH} 13.0$, there was a sharp decline in the activity. The $\mathrm{pH}$ stability of $\mathrm{PyCP}$ was examined by incubating the enzyme at 4 and $40^{\circ} \mathrm{C}$ for 16 and $1 \mathrm{~h}$, respectively, in the buffers of different $\mathrm{pH}$ values. PyCP was maximally stable at $\mathrm{pH} 8.0$ and retained over $77 \%$ of the activity after incubation for $16 \mathrm{~h}$ at $4^{\circ} \mathrm{C}$ over a wide $\mathrm{pH}$ range (4.0-10.0) (Figure 3B). When incubated at $40^{\circ} \mathrm{C}$ for $1 \mathrm{~h}$, the maximum activity $(100 \%)$ of the PyCP was observed at $\mathrm{pH} 8.0$, followed by 94 and $93 \%$ residual activity at $\mathrm{pH} 9.0$ and 10.0, respectively, whereas, relative activity of 40 and $36 \%$ was observed at $\mathrm{pH} 11.0$ and 12.0 , respectively. 


\section{Effect of Temperature on the Activity and Stability of Proteases Produced by Isolate S252}

Proteases produced by isolate S252 was highly active in the temperature range of $30-50^{\circ} \mathrm{C}$ and showed a maximum activity between 40 and $50^{\circ} \mathrm{C}$ (Figure 3C). At 10, 20, and $30^{\circ} \mathrm{C}, \mathrm{PyCP}$ showed 26,51 , and $81 \%$ relative activity, respectively.

Proteases produced by isolate S252 was highly stable at 40 and $50^{\circ} \mathrm{C}$ as it retained $100 \%$ activity after $30 \mathrm{~min}$ of incubation. After $120 \mathrm{~min}$ of incubation at 40 and $50^{\circ} \mathrm{C}, 95$ and $83 \%$ of the initial activity could be retained, respectively, indicating the thermostable nature of the protease (Figure 3D). The activity of the extracellular enzymes decreased significantly above $50^{\circ} \mathrm{C}$ and the residual activity of $36 \%$ was observed after incubation of the extracellular enzyme at $60^{\circ} \mathrm{C}$ for $15 \mathrm{~min}$.

\section{Effect of Metal lons and Inhibitors on Proteases Produced by Isolate S252}

The effect of various metal ions on PyCP activity was examined (Table 2). An increase in PyCP activity to about $180 \%$ was

TABLE 2 | Effect of metal ions and inhibitors on activity of PyCP.

\begin{tabular}{|c|c|c|}
\hline Metal ions & Concentration & Residual activity (\%) \\
\hline Control & & $100 \pm 0.3$ \\
\hline \multirow[t]{3}{*}{$\mathrm{Na}^{+}$} & $1 \mathrm{mM}$ & $114.07 \pm 1.2$ \\
\hline & $2 \mathrm{mM}$ & $182.79 \pm 2.5$ \\
\hline & $5 \mathrm{mM}$ & $179.21 \pm 2.8$ \\
\hline \multirow[t]{3}{*}{$\mathrm{Mg}^{2+}$} & $1 \mathrm{mM}$ & $105.25 \pm 5.6$ \\
\hline & $2 \mathrm{mM}$ & $165.90 \pm 3.0$ \\
\hline & $5 \mathrm{mM}$ & $145.85 \pm 2.6$ \\
\hline \multirow[t]{3}{*}{$\mathrm{Ag}^{+}$} & $1 \mathrm{mM}$ & $94.22 \pm 3.1$ \\
\hline & $2 \mathrm{mM}$ & $93.46 \pm 0.4$ \\
\hline & $5 \mathrm{mM}$ & $86.22 \pm 3.8$ \\
\hline \multirow[t]{3}{*}{$\mathrm{Ca}^{2+}$} & $1 \mathrm{mM}$ & $85.05 \pm 0.8$ \\
\hline & $2 \mathrm{mM}$ & $82.43 \pm 4.0$ \\
\hline & $5 \mathrm{mM}$ & $64.92 \pm 7.9$ \\
\hline \multirow[t]{3}{*}{$\mathrm{Zn}^{2+}$} & $1 \mathrm{mM}$ & $51.89 \pm 0.6$ \\
\hline & $2 \mathrm{mM}$ & $41.61 \pm 1.2$ \\
\hline & $5 \mathrm{mM}$ & $22.77 \pm 3.0$ \\
\hline \multirow[t]{3}{*}{$\mathrm{Cu}^{2+}$} & $1 \mathrm{mM}$ & $180.05 \pm 5.5$ \\
\hline & $2 \mathrm{mM}$ & $155.70 \pm 0.3$ \\
\hline & $5 \mathrm{mM}$ & $141.64 \pm 1.6$ \\
\hline \multirow[t]{3}{*}{$\mathrm{Co}^{2+}$} & $1 \mathrm{mM}$ & $114.86 \pm 0.8$ \\
\hline & $2 \mathrm{mM}$ & $101.89 \pm 2.9$ \\
\hline & $5 \mathrm{mM}$ & $101.13 \pm 2.2$ \\
\hline \multicolumn{3}{|l|}{ Inhibitors } \\
\hline \multirow[t]{2}{*}{ PMSF } & $1 \mathrm{mM}$ & $100.15 \pm 1.5$ \\
\hline & $2.5 \mathrm{mM}$ & $109.67 \pm 8.7$ \\
\hline \multirow[t]{2}{*}{ Aprotonin } & $1 \mathrm{mM}$ & $96.23 \pm 0.6$ \\
\hline & $2.5 \mathrm{mM}$ & $93.25 \pm 2.6$ \\
\hline \multirow[t]{2}{*}{ EDTA } & $1 \mathrm{mM}$ & $97.40 \pm 3.7$ \\
\hline & $2.5 \mathrm{mM}$ & $107.60 \pm 2.1$ \\
\hline$\beta$-mercaptoethanol & $10 \mathrm{mM}$ & $5.0 \pm 3.3$ \\
\hline
\end{tabular}

PyCP was incubated with different concentration of metal ions and inhibitors for $60 \mathrm{~min}$ at $40^{\circ} \mathrm{C}$ and the remaining activity was measured under standard assay conditions. observed in the presence of $1 \mathrm{mM} \mathrm{Cu}{ }^{2+}, 2 \mathrm{mM} \mathrm{Na}^{+}$, and $5 \mathrm{mM} \mathrm{Na}^{+}$. The addition of $2 \mathrm{mM} \mathrm{Mg}^{2+}$ and $1 \mathrm{mM} \mathrm{Co}^{2+}$ increased the relative activity of the enzyme to 166 and $115 \%$, respectively. Furthermore, the relative activity showed a slight decrease to 94 and $85 \%$ in the presence of $1 \mathrm{mM} \mathrm{Ag}^{+}$and $1 \mathrm{mM}$ $\mathrm{Ca}^{2+}$, respectively.

Phenylmethylsulfonyl fluoride (serine protease inhibitor) and EDTA (metalloprotease inhibitor) did not exhibit any significant effect on activity of $\mathrm{PyCP}$ at the concentration of 1 and $2.5 \mathrm{mM}$, respectively (Table 2). Furthermore, in the presence of 1 and $2.5 \mathrm{mM}$ aprotonin (cysteine protease inhibitor), the enzyme did not show a significant change in residual activity as compared with the control whereas $\beta$-ME completely inhibited the activity of PyCP.

\section{Effect of Surfactants and Oxidants on Proteases Produced by Isolate S252}

Proteases produced by isolate S252 was highly stable in the presence of Triton X-100 and Tween-20 showing an increase in the relative activity to 106 and $135 \%$, respectively at $2.5 \%$ concentration of each detergent (Table 3). PyCP retained $80 \%$ activity in $0.1 \%$ SDS and $\sim 57 \%$ residual activity in 0.5 and $1.0 \%$ SDS. PyCP showed activity of 150,162 , and $119 \%$ relative to the control in 1, 2.5, and $5 \% \mathrm{H}_{2} \mathrm{O}_{2}$, respectively (Table 3). PyCP was markedly stable in the presence of 1 and $5 \%$ glycerol, showing 102 and $120 \%$ relative activity, respectively as compared with the control. The enzymes were compatible with PEG 8000 also, retaining 86 and $80 \%$ activity when incubated in 1 and 5\% PEG 8000 , respectively for $60 \mathrm{~min}$ at $40^{\circ} \mathrm{C}$.

\section{Stability of Proteases Produced by Isolate S252 Toward Organic Solvents}

Proteases produced by isolate S252 was examined against some commonly used organic solvents (Table 4). PyCP was remarkably

TABLE 3 | Stability of PyCP in the presence of surfactants, oxidant and polyols.

\begin{tabular}{lcc}
\hline Additives & Concentration & Residual activity (\%) \\
\hline Glycerol & $1 \%$ & $101.76 \pm 2.4$ \\
PEG 8000 & $5 \%$ & $119.96 \pm 2.0$ \\
& $1 \%$ & $86.08 \pm 1.0$ \\
Triton $\mathrm{X}-100$ & $5 \%$ & $79.65 \pm 2.4$ \\
& $1 \%$ & $102 \pm 3.1$ \\
Tween 20 & $2.50 \%$ & $106.66 \pm 5.5$ \\
& $5 \%$ & $101.50 \pm 7.6$ \\
& $1 \%$ & $130 \pm 3.4$ \\
$\mathrm{H}_{2} \mathrm{O}_{2}$ & $2.50 \%$ & $135 \pm 7.0$ \\
& $5 \%$ & $90 \pm 1.6$ \\
& $1 \%$ & $149.78 \pm 2.4$ \\
SDS & $2.50 \%$ & $162 \pm 4.8$ \\
& $5 \%$ & $119 \pm 10.8$ \\
& $0.10 \%$ & $79.63 \pm 9.4$ \\
& $0.50 \%$ & $57.20 \pm 4.1$ \\
& $1 \%$ & $56.78 \pm 2.7$
\end{tabular}

PyCP was incubated with different concentration of various additives for 60 min at $40^{\circ} \mathrm{C}$ and the remaining activity was measured under standard assay conditions. 
TABLE 4 | Effect of organic solvents on activity of PyCP.

\begin{tabular}{lc}
\hline Solvents & Residual activity (25\%) \\
\hline Chloroform & $40.01 \pm 2.5$ \\
Butanol & $22.57 \pm 11.1$ \\
Methanol & $82.39 \pm 1.1$ \\
Ethanol & $72.20 \pm 2.3$ \\
Formaldehyde & $8.04 \pm 6.8$ \\
Acetone & $89.39 \pm 0.3$ \\
Formamide & $100.85 \pm 0.5$ \\
Isopropanol & $51.97 \pm 2.8$ \\
\hline
\end{tabular}

PyCP was incubated with $25 \%$ of the solvent for 60 min at $40^{\circ} \mathrm{C}$ and the residual activity was measured under standard assay conditions.

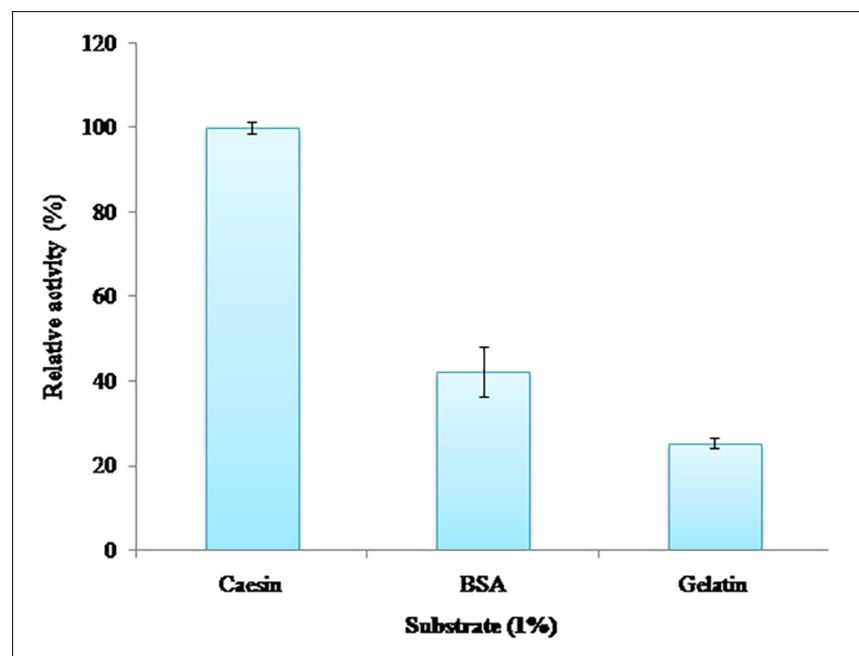

FIGURE 4 | Substrate specificity of PyCP.

stable in formamide (retaining 100\% activity), acetone (90\% residual activity), and methanol ( $82 \%$ residual activity). $\mathrm{PyCP}$ showed moderate inhibition (28\%) in ethanol whereas $48 \%$ inhibition was observed in isopropanol. Chloroform and butanol had detrimental effect on the activity of PyCP.

\section{Substrate Specificity}

Among casein, gelatin, and BSA, casein was the most preferred substrate of PyCP followed by BSA and gelatin, retaining the relative activity of 42 and 24\%, respectively (Figure 4).

\section{Potential of Proteases Produced by Isolate S252 in Detergent Formulations Compatibility With Commercial Detergents}

The stability of PyCP was evaluated in various commercially available detergents (liquid detergent, 1:100, $v / v$; detergent powder, $7 \mathrm{mg} / \mathrm{ml}$ ) after incubation for $60 \mathrm{~min}$ at $40^{\circ} \mathrm{C}$ (Figure 5). PyCP was extremely stable in liquid detergent Ezee retaining $95 \%$ of the initial activity whereas in solid detergents, it was stable in Vanish-Oxi action (containing $>30 \%$ oxygen based bleaching agent) and Tide showing residual activity of 80 and $74 \%$, respectively. In Ariel and Surf, PyCP lost considerable activity (62\% residual activity).

\section{Wash Performance Evaluation}

As PyCP showed high activity in $\mathrm{pH}$ range from 10.0 to 12.0 and was stable in surfactants, ion chelator (EDTA), and oxidant $\left(\mathrm{H}_{2} \mathrm{O}_{2}\right)$, the application of PyCP was evaluated by assessing its washing performance on clean cotton cloth pieces stained with tomato ketchup, coffee, and blood. The stained cloth pieces were washed with commercial detergent Vanish $(7 \mathrm{mg} / \mathrm{ml})$, heatinactivated Vanish, PyCP in inactivated Vanish and water. PyCPsupplemented inactivated Vanish showed better stain removal ability as compared with water or only Vanish on the stained cloth pieces (Figure 6). Visual appearance of better cleaning was supported by quantitative evaluation where it was evident that PyCP improved the wash performance by 46,8 , and $2 \%$ to remove tomato ketchup and coffee and blood stains, respectively as compared with Vanish. Blood-stained cloth pieces showed significantly enhanced wash performance in PyCP-supplemented heated Vanish as compared with heated Vanish whereas no significant difference was detected in wash performance between Vanish and heated Vanish.

\section{Gelatin Hydrolysis in Waste X-Ray Film for Silver Recovery}

Proteases produced by isolate S252 can be efficiently used for the recovery of silver from the used X-ray film by hydrolyzing gelatin. At $\mathrm{pH} 8.0$ and $\mathrm{pH}$ 12.0, the enzymes showed hydrolysis of gelatin within 25 min leaving a clean polyester sheet while releasing silver into the medium (Figure 7). The turbidity of reaction mix increased till $25 \mathrm{~min}$ after which no further increase in the turbidity was observed.

\section{Potential of Proteases Produced by Isolate S252 in Dehairing}

Proteases produced by isolate S252 was evaluated for its potential for dehairing goat skin at the optimum temperature. After the treatment of goat skin with PyCP for $24 \mathrm{~h}$ at $40^{\circ} \mathrm{C}$, hair could be easily removed from the skin, imparting smooth texture to the surface (Figure 8).

\section{Deproteinization of Crustacean Shells for Extraction of Chitin}

In crustacean shells, proteins hold the chitin exoskeleton of shrimp shells in a close association making deproteinization crucial in the process of extraction of chitin. The potential of PyCP in extraction of chitin from crustacean shells was evaluated at $\mathrm{pH} 8$ as the enzyme showed maximum stability at $\mathrm{pH} 8$ for $1 \mathrm{~h}$ (Figure 3B). The action of $\mathrm{PyCP}$ on shrimp shells at enzyme/substrate ratio (E/S) of $20 \mathrm{U} / \mathrm{mg}$ resulted in deproteinization of $84 \%$ after $6 \mathrm{~h}$ (Table 5). In comparison, $20 \mathrm{U} / \mathrm{mg}$ papain and alcalase showed 32 and $36 \%$ deproteinization of shrimp shells, respectively after $6 \mathrm{~h}$ of incubation, highlighting the importance of PyCP in the environment-friendly process of bioextraction of chitin. Extraction of chitin was evident in FTIR analysis of the deproteinized shrimp shell that showed chitin characteristic bands while maintaining the polysaccharide structure (Figure 9). The spectrum obtained for shrimp shell chitin extracted using PyCP showed bands at $1,651,1,550$, and $1,320 \mathrm{~cm}^{-1}$ that 


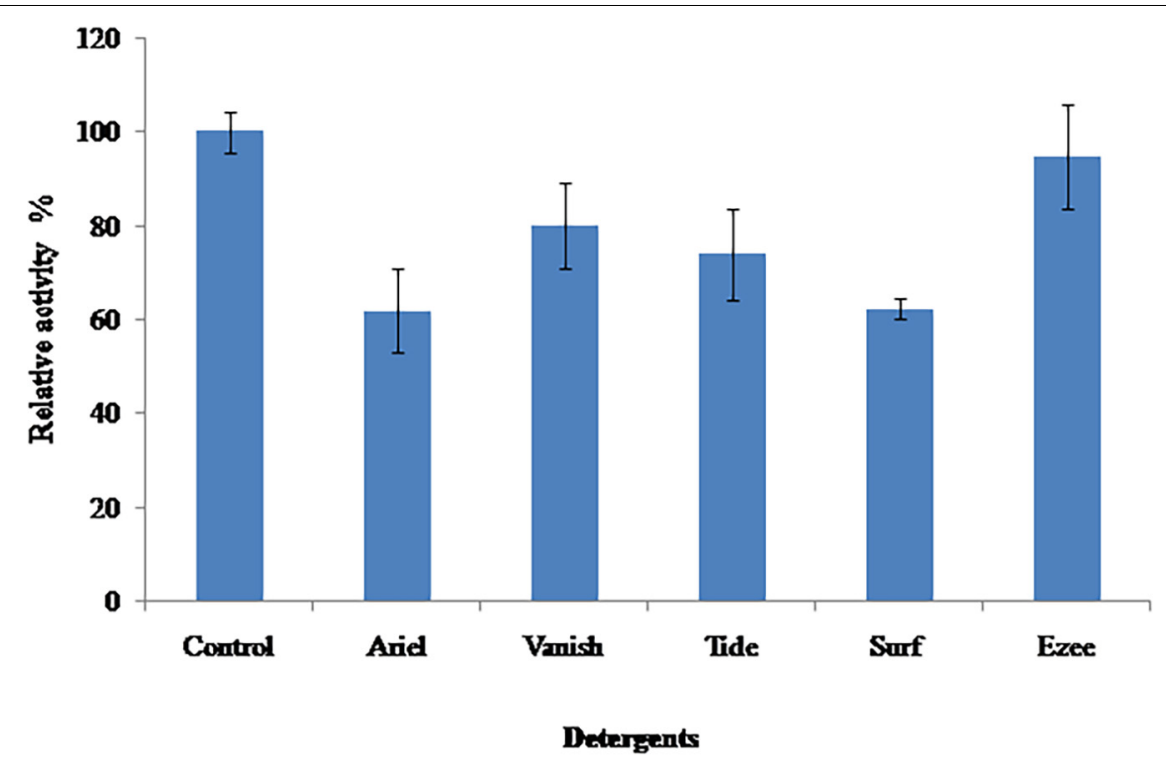

FIGURE 5 | Effect of commercial detergents on stability of PyCP.

correspond to the amide $\mathrm{I}$ stretching of $\mathrm{C}=\mathrm{O}$, the amide II of $\mathrm{N}-\mathrm{H}$, and amide III of $\mathrm{C}-\mathrm{N}$, respectively. Moreover, IR peaks obtained at 3,435 and $2,932 \mathrm{~cm}^{-1}$ is comparable with vibration of $-\mathrm{OH}$ and $-\mathrm{CO}-\mathrm{CH}_{3}$ group, respectively. In addition to this deproteinization of shrimp shell using $\mathrm{PyCP}$ showed a significant effect on the surface of shells as evident from the scanning electron micrographs. Before treatment, the shell surface appeared smooth and intact whereas after treatment with PyCP, the surface appeared fractured with abrasions (Figures 10A,B). This suggests that PyCP treatment altered the compact structure of shrimp shells presumably resulting from extraction of protein. The surface of alcalase-treated shells appeared less deformed as compared with PyCP-treated shells (Figure 10).

\section{DISCUSSION}

Pyxidicoccus sp. S252, isolated from soil sample, exhibited potent proteolytic activity. The extracellular proteases secreted by the myxobacterial strain S252 were characterized. The limited studies on extracellular proteases secreted by myxobacteria have implicated their role in the life cycle of the host under nutrient-deprived conditions, but their potential applications in the biotechnology applications remain unexplored (Petit and Guespin-Michel, 1992; Dumont et al., 1994). The zymogram of PyCP showed at least six caseinolytic bands ranging from 15 to $50 \mathrm{kDa}$, suggesting the production of at least six extracellular proteases by isolate S252. The occurrence of extracellular proteases as complexes has been reported in Myxococcus virescens, but to the best of our knowledge, there is no report of proteases from Pyxidicoccus spp. till date (Gnosspelius, 1978).

The activity and stability of $\mathrm{PyCP}$ in the alkaline $\mathrm{pH}$ range makes it suitable as an additive in detergent formulations and in dehairing of the skin in the leather industry (Abdel Fattah et al., 2016; Suginta et al., 2016; Champasri et al., 2021; Li et al., 2021). The $\mathrm{pH}$ optimum of commercial detergent proteases (Savinase,

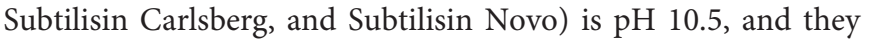
are stable in the $\mathrm{pH}$ range 7.0-12.0 (Niyonzima and More, 2015). The crude proteases from Bacillus invictae were also active in $\mathrm{pH}$ range of 9.0-11.0 and could effectively remove blood stains from clothes when added in detergent (Hammami et al., 2017). An alkaline protease from $M$. xanthus (myxobacterium) exhibiting the maximum activity at $40^{\circ} \mathrm{C}$ and $\mathrm{pH} 8.5$ has been reported, but it was not checked for potential application in the biotechnology industry (Dumont et al., 1994).

The proteases in PyCP had optimal temperatures of $40-50^{\circ} \mathrm{C}$ and retained more than $80 \%$ activity after $120 \mathrm{~min}$ at $50^{\circ} \mathrm{C}$. Alkaline proteases that are active at temperature around 40$50^{\circ} \mathrm{C}$ are generally required for detergent industries (Mothe and Sultanpuram, 2016). Alcalase, Savinase, and Maxatase are the commercially used alkaline proteases which have temperature optima between 50 and $60^{\circ} \mathrm{C}$ (Beg and Gupta, 2003). Thus, PyCP fulfills the desired characteristics of the proteases required in detergent formulations for which high activity at alkaline $\mathrm{pH}$ range along with the thermostability is a pre-requisite (Ramkumar et al., 2018). Moreover, PyCP shows $>80 \%$ relative activity at $30^{\circ} \mathrm{C}$, indicating its utility in lower-temperature wash programs making the process energy efficient. It would also be useful in washing of branded garments which are usually not recommended to be washed at higher temperatures (Al-Ghanayem and Joseph, 2020).

It has been well documented that metal ions act as cofactors for proteases, and they either stimulate or inhibit the enzyme catalysis. Several metal ions $\left(\mathrm{Mg}^{2+}\right.$ and $\left.\mathrm{Ca}^{2+}\right)$ enhanced the activity of PyCP which further indicated the suitability of the enzymes in laundry detergents for washing in hard water where positively charged $\mathrm{Mg}^{2+}$ and $\mathrm{Ca}^{2+}$ are present. Several proteases 

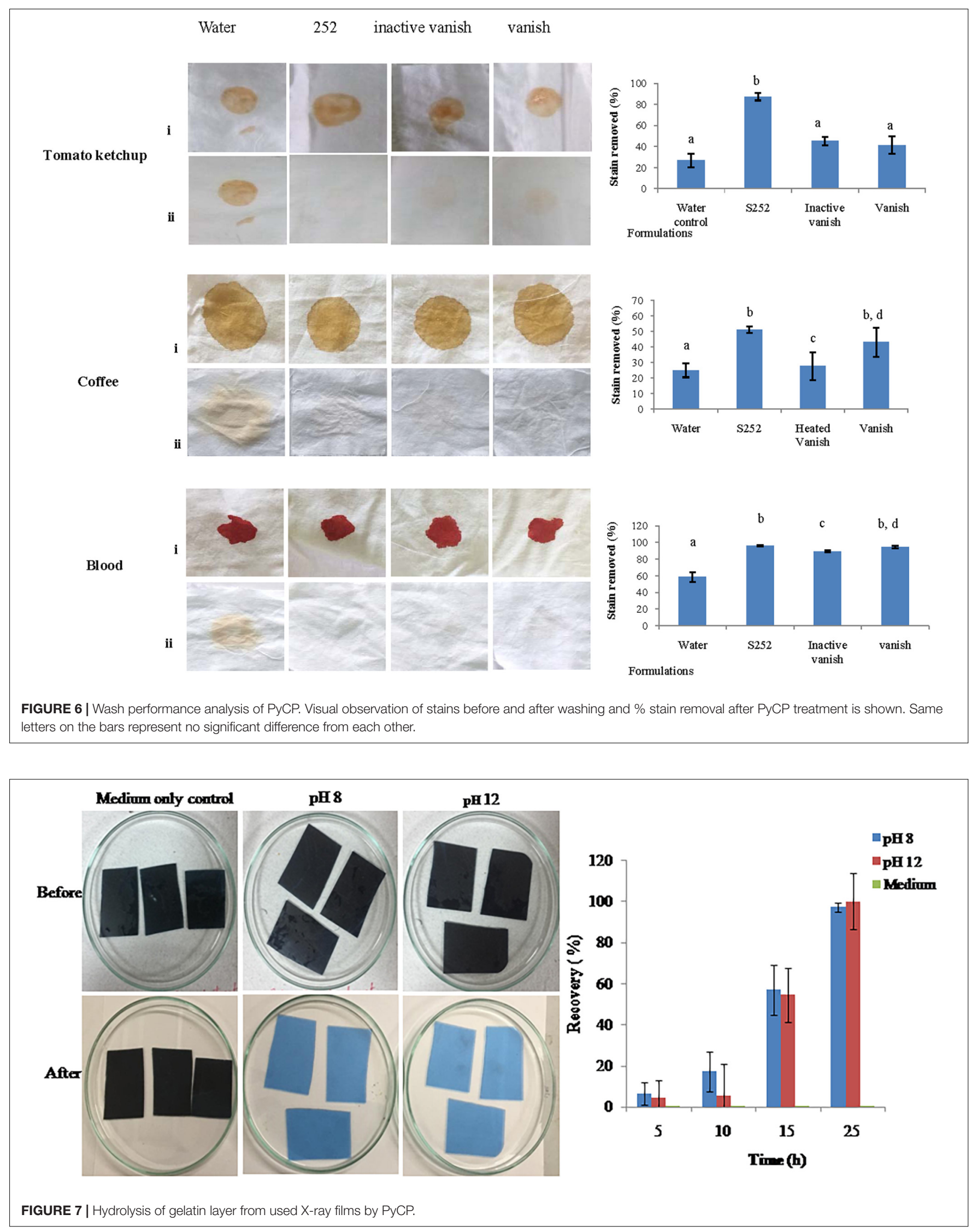


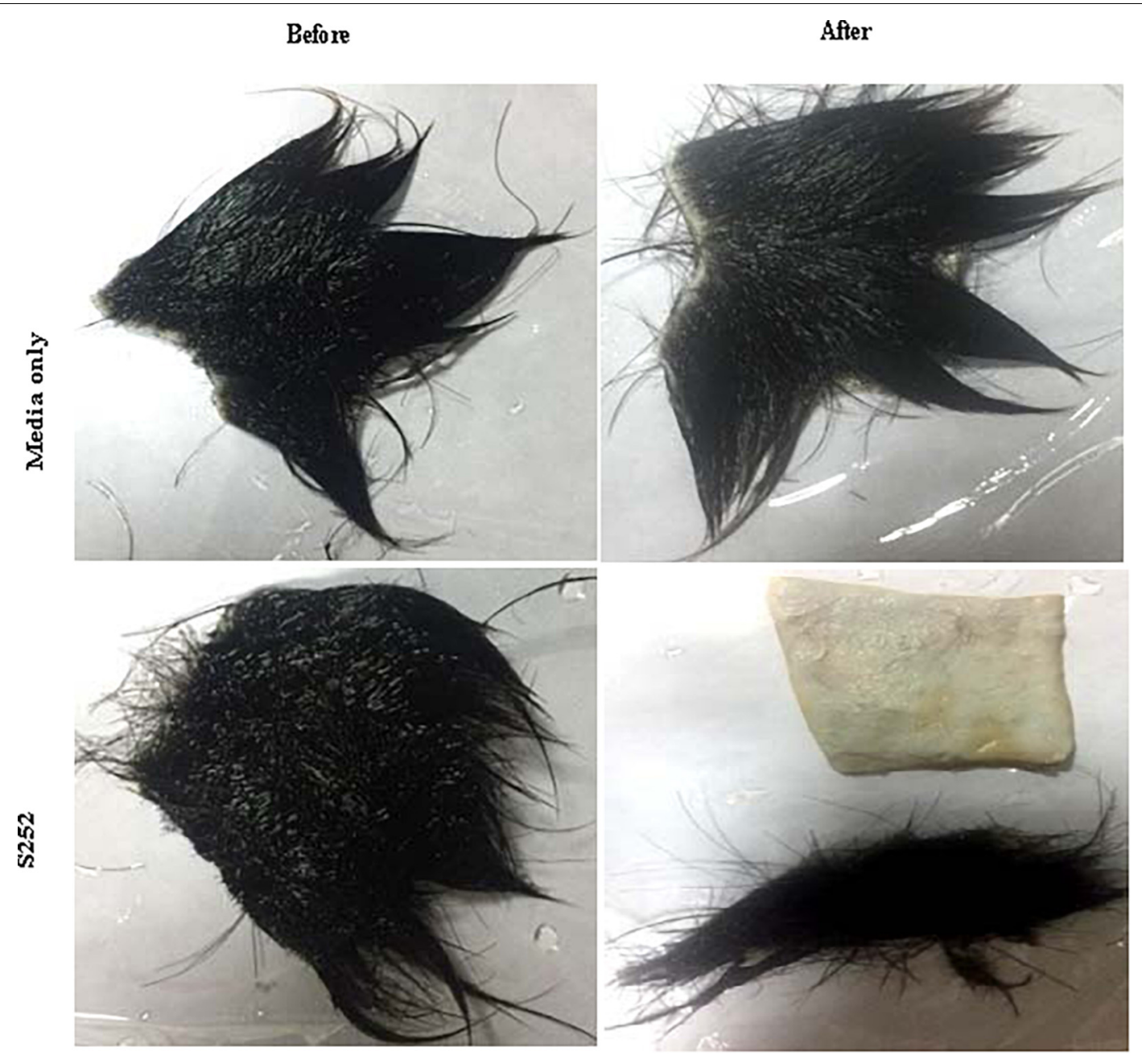

FIGURE 8 | Dehairing potential of PyCP. Goat skin was incubated for $24 \mathrm{~h}$ at $40^{\circ} \mathrm{C}$ with PyCP.

from Bacillus spp., $\mathrm{Ca}^{2+}$ and $\mathrm{Mg}^{2+}$ ions have been reported to stimulate alkaline protease activity (Deng et al., 2010; Annamalai et al., 2014; Yang et al., 2020).

The influence of various protease inhibitors on enzyme activity generally provides insights into the nature of enzyme, active site, and the cofactors required for its activity (Arulmani et al., 2007; Doddapaneni et al., 2009). It was observed that EDTA (metalloprotease inhibitor) did not exert any significant effect on the activity of PyCP, which suggested that PyCP might not contain metalloproteases that require metallic ions for their activity or EDTA could not extract $\mathrm{Ca}^{2+}$ bound tightly to the enzymes. The stability of proteases in chelating agents like EDTA make them suitable as an additive in detergents as chelating agents are components of most detergents (Beg and Gupta, 2003). As $\beta$-ME completely inhibited the activity of PyCP, it is possible that disulfide bonds are required for maintaining the active conformation of the proteases.

To be used as additive in the detergents, proteases should be compatible with surfactants, oxidants, and other additives. Anionic detergents are most widely used additives in detergent industries because they do not allow the dirt that has been removed from the fabric to reattach to the fabric. In general, proteases are reported to be inhibited in the presence of strong anionic detergent SDS necessitating the requirement for proteases that are stable against SDS (Tatineni et al., 2008; Amid et al., 2014). PyCP showed stability as well as enhanced activity in

TABLE 5 | Deproteinization potential of PyCP.

\begin{tabular}{llc}
\hline S. No. & Enzyme & Deproteinization (\%) \\
\hline 1 & PyCP & $\mathbf{8 4 . 7 5} \pm 0.67$ \\
2 & Alcalase $^{\star}$ & $36.59 \pm 3.89$ \\
3 & Papain $^{\star *}$ & $32.47 \pm 6.01$ \\
\hline
\end{tabular}

The data is represented as mean \pm standard error of mean of three independent experiments.

*optimum $\mathrm{pH}=8$.

**optimum $\mathrm{pH}=6$.

Each deproteinization was carried out at E/S of $20 \mathrm{U} / \mathrm{mg}$ at $40^{\circ} \mathrm{C}$ for $6 \mathrm{~h}$.

Bold values highlight strain S252 and deproteinization activity of protease produced by S252 (PyCP). 


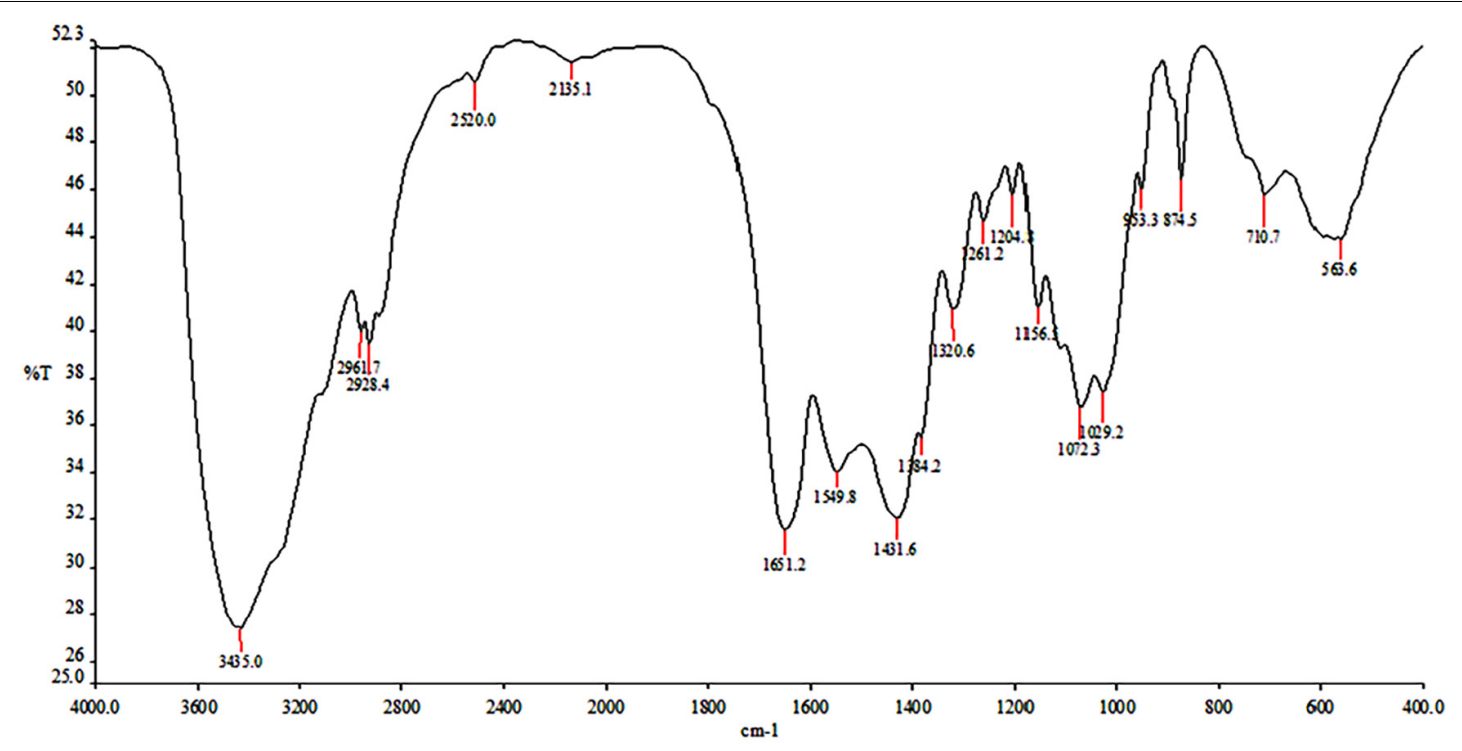

FIGURE 9 | FTIR spectrum of extracted shrimp shell chitin.

A

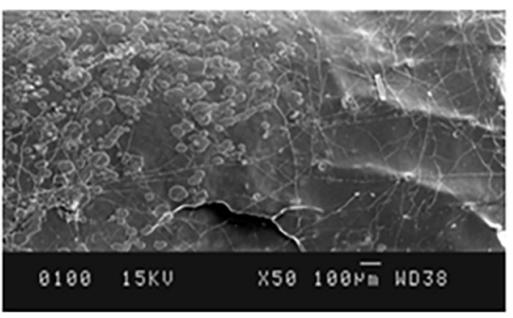

B

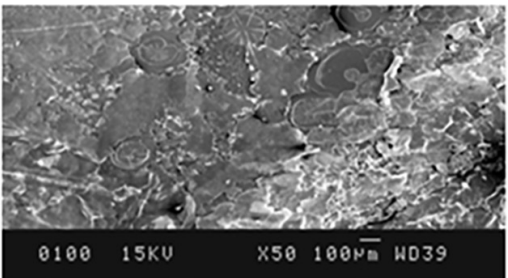

C

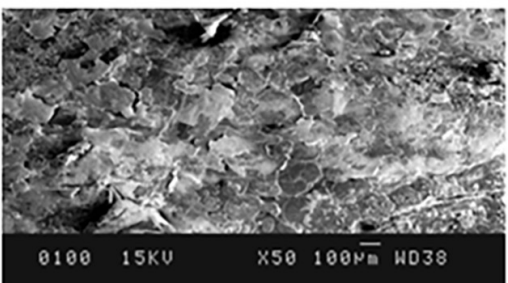

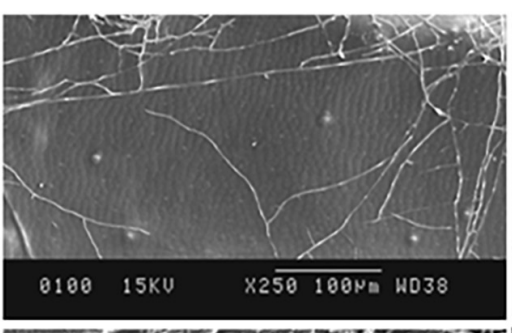
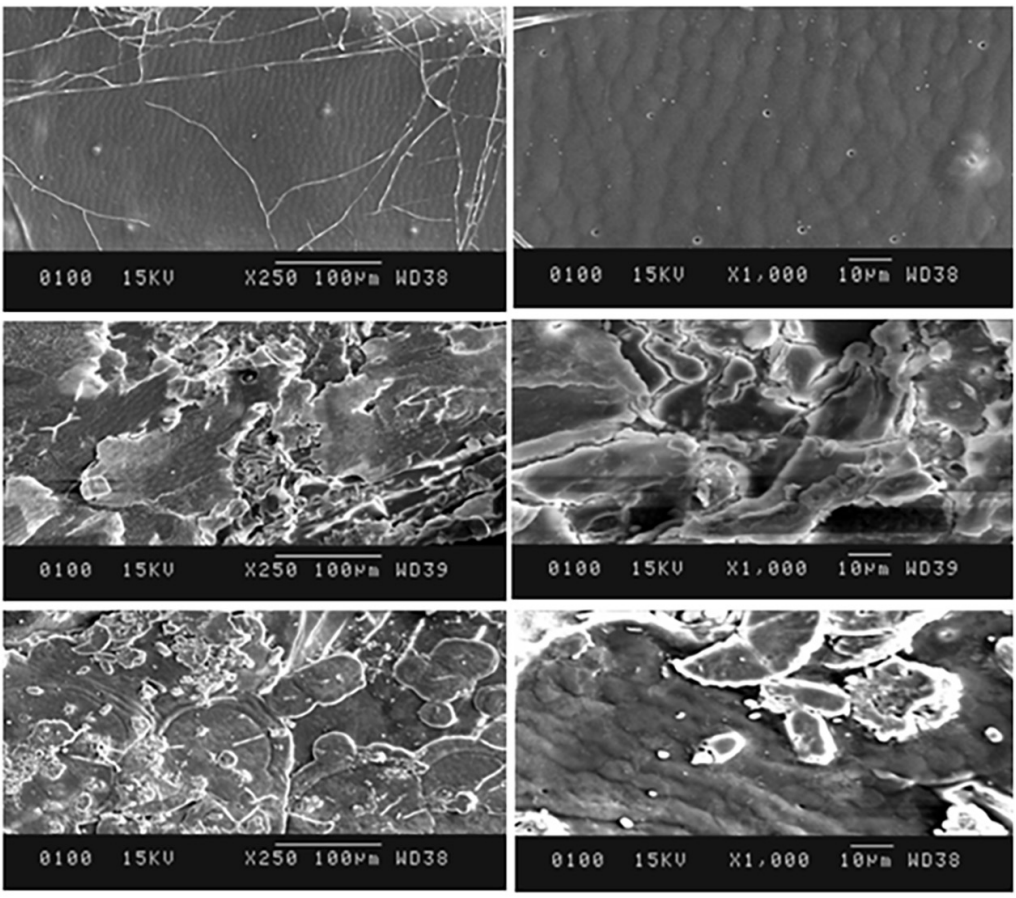

FIGURE 10 | SEM images of shrimp shells (A) before treatment, (B) PyCP, and (C) alcalase.

presence of non-ionic detergents (Triton X-100 and Tween-20), whereas more than $80 \%$ residual activity was observed in the presence of $0.1 \%$ SDS. The compatibility of PyCP with SDS makes it a promising candidate in the detergent industry where SDS is an unavoidable additive. The crude alkaline proteases from $B$. invictae showed residual activity of $93 \%, 20 \%$ in 0.1 , and $0.5 \%$ SDS, respectively (Hammami et al., 2017). $\mathrm{H}_{2} \mathrm{O}_{2}$ is a strong oxidant which inactivates the enzymes very rapidly
(Yu et al., 2019). PyCP not only showed resistance to a very strong oxidizing agent, $\mathrm{H}_{2} \mathrm{O}_{2}$, but also showed a $62 \%$ increase in its activity in its presence. Thus, the resistance of PyCP to $\mathrm{H}_{2} \mathrm{O}_{2}$ reinforces its suitability as an additive in detergents. In literature, very few alkaline proteases have been reported to tolerate $\mathrm{H}_{2} \mathrm{O}_{2}$. The alkaline proteases from Idiomarina sp. C9-1 showed enhanced activity of 129 and $126 \%$ at 1 and $2 \% \mathrm{H}_{2} \mathrm{O}_{2}$, respectively (Zhou et al., 2018). The alkaline proteases from 
B. invictae and Micromonospora chaiyaphumensis S103 showed 96 and $78 \%$ activity in $1 \% \mathrm{H}_{2} \mathrm{O}_{2}$, respectively; whereas the activity dropped to 77 and $37 \%$ in $5 \% \mathrm{H}_{2} \mathrm{O}_{2}$, respectively (Hammami et al., 2017; Mhamdi et al., 2017). Furthermore, PyCP was also compatible with glycerol and PEG which are used as stabilizers of enzymes in commercial detergents.

The stability of PyCP in formamide, acetone, and methanol indicate the potential of PyCP as biocatalysts in organic synthesis (Doukyu and Ogino, 2010).

To be suitable for various applications, alkaline proteases should have broad substrate specificity. The order of preference of substrates used by $\mathrm{PyCP}$ was casein $>$ BSA $>$ gelatin. This suggests, that in addition to the capability of PyCP to remove a wide variety of protein stains from clothes, the enzymes can be also explored for their potential in preparation of casein hydrolysates for use in functional foods and pharmaceutical industry (Tu et al., 2018; Shazly et al., 2019).

The largest share of alkaline proteases is used in laundry detergents as bioadditives because the addition of enzymes confers better washing attributes on the detergent and have the ability to replace some chemicals to make them environmentally compatible (Singh et al., 2018; Zhang et al., 2019). Proteases hydrolyze proteinaceous material in the stain, thus improving the washing efficiency in environmentally compatible, nonphosphate detergents (Maase and van Tilburg, 1983; Jain et al., 2012). Moreover, the use of crude proteases in detergents is economically viable due to the low cost incurred in their preparation as compared with the purified proteases (Paul et al., 2014). The use of alkaline proteases in stain removal from clothes requires the protease to be compatible with ingredients contained in the commercial detergents which adversely affect the stability of the proteases (Reddy et al., 2017). PyCP was highly stable in the liquid detergent Ezee retaining 95\% activity. Very few proteases are known to be stable in liquid detergents (Zhang et al., 2019). The increase in preference for liquid detergents among consumers makes PyCP a promising candidate as supplement in liquid detergents. In addition to liquid detergent, the stability of PyCP in the commercial detergent powders (Tide and VanishOxi) suggests the utility of PyCP as an additive in powder detergents also. Several studies have reported variable stability and compatibility of alkaline proteases produced by diverse microorganisms in different commercial detergents (Banik and Prakash, 2004; Abidi et al., 2011; Abdel Wahab and Ahmed, 2018; Ibrahim et al., 2019). Further PyCP was evaluated for washing performance wherein PyCP showed enhanced washing performance against different stains (ketchup, coffee, and blood) as compared with the commercially available detergent VanishOxi. The discoloration of blood stains was obtained by using proteases from Penicillium chrysogenum and Neocosmospora sp. N1 (Benmrad et al., 2018; Matkawala et al., 2019).

The potential applications of PyCP in hydrolysis of gelatin in X-ray film for silver recovery, hide dehairing and deproteinization of sea waste were also assessed. The exposed X-ray films contribute to $18-20 \%$ of silver production worldwide. The conventional method to recover silver from the used X-ray films involves burning the film which results in air pollution (Singh and Bajaj, 2017). Other methods using chemicals have also been developed to extract silver from films which are hazardous to the environment (Zhouxiang et al., 2008). The use of alkaline proteases to remove silver containing gelatin is an environmental friendly option (Masui et al., 2004). PyCP can be efficiently used for the recovery of silver from the used X-ray film by hydrolyzing gelatin. This allows the polyester sheet thus obtained to be reused for manufacturing X-ray film or put into other uses. Silver recovery from X-ray film in $120 \mathrm{~min}$ has been recently reported by Thomas et al. (2020).

In the leather industry, animal skins are subjected to treatment with lime and sodium sulfide for dehairing. These toxic chemicals are released as effluents into the water bodies resulting in environmental pollution (Thanikaivelan et al., 2004; Sivasubramanian et al., 2008). There is an increasing shift and interest toward adopting enzymatic processes in leather industry to reduce pollution and also to improve leather quality. Leather industries require lot of water and the physicochemical properties of water would vary depending on season and source (George et al., 2014). PyCP fulfills the requirement of the enzyme that is active and stable in a wide temperature and $\mathrm{pH}$ range making it suitable for use in the leather industry. PyCP showed promising results by removing hair and resulting in smooth clear skin. Dehairing of skin has been reported by alkaline proteases produced by Bacillus sp. and Vibrio sp. CA1-1 (George et al., 2014; Chen et al., 2018; Hammami et al., 2018).

Proteases produced by isolate S252-treated (20 U/mg) shrimp shells resulted in deproteinization of $84 \%$ after $6 \mathrm{~h}$. Several proteases from Bacillus spp., Aspergillus sp., and Vibrio sp. have shown $65 \%-76 \%$, deproteinization of shrimp shells after $3 \mathrm{~h}$ incubation at $50^{\circ} \mathrm{C}$ with $\mathrm{E} / \mathrm{S}$ ratios of $20 \mathrm{U} / \mathrm{mg}$ of protein for bioextraction of chitin (Younes et al., 2012). Deproteinization for chitin extraction from shrimp shell was evident in FTIR spectrum, which was comparable with those of chitin extracted from other sources. The spectrum obtained for shrimp shell chitin extracted using PyCP showed bands at 1,651, 1,550, and $1,320 \mathrm{~cm}^{-1}$ that were comparable with three significant amide bands at $1,654,1,560$, and $1,310 \mathrm{~cm}^{-1}$, which correspond to the amide I stretching of $\mathrm{C}=\mathrm{O}$, the amide II of $\mathrm{N}-\mathrm{H}$, and amide III of $\mathrm{C}-\mathrm{N}$, respectively; moreover, IR peaks obtained at 3,435 and $2,932 \mathrm{~cm}^{-1}$ is comparable with vibration of $\mathrm{OH}$ and $-\mathrm{CO}-\mathrm{CH}_{3}$ group, respectively for shrimp shell chitin (Liu et al., 2012; Zhang et al., 2021). SEM showed surface abrasion in shrimp shell cell surface morphology which is similar surface deformation that was observed after the successive twostep fermentation treatment with Serratia marcescens B742 and Lactobacillus plantarum ATCC 8014 (Zhang et al., 2012). The potential of PyCP for deproteinization of shrimp shells can be further explored by optimizing the $\mathrm{E} / \mathrm{S}$ ratio, temperature, $\mathrm{pH}$, and time of incubation for efficient extraction of chitin. The present study reveals the potential of proteases from Pyxidicoccus sp. S252 in commercial processes to make them ecofriendly.

\section{CONCLUSION}

A new myxobacterial strain, identified as Pyxidicoccus sp. S252, secreted extracellular proteases which were active over 
a wide range of $\mathrm{pH}$ and temperature. The alkaline $\mathrm{PyCP}$ were stable in several detergent components (surfactants, oxidizing agent, and EDTA) and showed a remarkable washing performance when added to the commercial laundry detergent. Moreover, the enzymes showed excellent gelatin hydrolysis activity on X-ray film exhibiting their potential in silver recovery from X-ray films. Isolate S252 proteases also showed potent dehairing of goat skin and potent deproteinization of crustacean shells. Thus, the present study, for the first time, highlights the potential of alkaline proteases produced by Pyxidicoccus sp. in multiple industrial processes. Our future studies are aimed at assessment of extracellular enzymes for commercial exploitation and purification of the enzymes to assess their importance in pharmaceutical industry.

\section{DATA AVAILABILITY STATEMENT}

The datasets presented in this study can be found in online repositories. The names of the repository/repositories and

\section{REFERENCES}

Abdel Fattah, A., Ashoush, I., and Alnashi, B. (2016). Effect of chitosan edible coating on quality attributes of pomegranate arils during cold storage. J. Food. Dairy Sci. 7, 435-442. doi: 10.21608/jfds.2016.46049

Abdel Wahab, W. A., and Ahmed, S. A. (2018). Response surface methodology for production, characterization and application of solvent, salt and alkali-tolerant alkaline protease from isolated fungal strain Aspergillus niger WA 2017. Int. J. Biol. Macromol. 115, 447-458. doi: 10.1016/j.ijbiomac.2018.04.041

Abidi, F., Chobert, J. M., Haertlé, T., and Marzouki, M. N. (2011). Purification and biochemical characterization of stable alkaline protease Prot- 2 from Botrytis cinerea. Process. Biochem. 46, 2301-2310. doi: 10.1016/j.procbio.2011.09.010

Al-Ghanayem, A. A., and Joseph, B. (2020). Current prospective in using coldactive enzymes as eco-friendly detergent additive. Appl. Microbiol. Biotechnol. 104, 2871-2882. doi: 10.1007/s00253-020-10429-x

Amid, M., Abd Manap, M. Y., and Zohdi, N. K. (2014). Purification and characterization of alkaline-thermostable protease enzyme from pitaya (Hylocereus polyrhizus) Waste: a Potential low cost of the enzyme. Biomed. Res. Int. 2014:259238. doi: 10.1155/2014/259238

Annamalai, N., Rajeswari, M. V., and Balasubramanian, T. (2014). Extraction, purification and application of thermostable andhalostable alkaline protease from Bacillus alveayuensis CAS 5using marine wastes. Food Bioprod. Process. 92, 335-342. doi: 10.1016/j.fbp.2013.08.009

Arulmani, M., Aparanjini, K., Vasanthi, K., Arumugam, P., Arivuchelvi, M., and Kalaichelvan, P. T. (2007). Purification and partial characterization of serine protease from thermostable alkalophilic Bacillus laterosporus-AK1. World J. Microbiol. Biotechnol. 23, 475-481. doi: 10.1007/s11274-006-9249-7

Asgher, M., Bashir, F., and Iqbal, H. M. N. (2018). Protease-based cross-linked enzyme aggregates with improved catalytic stability, silver removal, and dehairing potentials. Int. J. Biol. Macromol. 118, 1247-1256. doi: 10.1016/j. ijbiomac.2018.06.107

Banerjee, G., and Ray, A. K. (2017). Impact of microbial proteases on biotechnological industries. Biotechnol. Genet. Eng. Rev. 33, 119-143. doi: 10. 1080/02648725.2017.1408256

Banik, R. M., and Prakash, M. (2004). Laundry detergent compatibility of the alkaline protease from Bacillus cereus. Microbiol. Res. 159, 135-140. doi: 10. 1016/j.micres.2004.01.002

Beg, Q. K., and Gupta, R. (2003). Purification and characterization of an oxidationstable, thiol-dependent serine alkaline protease from Bacillus mojavensis. Enzyme Microb. Technol. 32, 294-304. doi: 10.1016/S0141-0229(02)00293-4

Benmrad, M. O., Moujehed, E., Elhoul, M. B., Mechri, S., Bejar, S., Zouari, R., et al. (2018). Production, purification, and biochemical characterization of serine accession number(s) can be found below: https://www.ncbi.nlm. nih.gov/genbank/, KT983642.

\section{AUTHOR CONTRIBUTIONS}

SS designed and carried out the experiments and prepared the first draft of the manuscript. SK isolated the strain and did preliminary screening. RamK conceived the study, supervised the work, and revised the manuscript. RajK analyzed the results and finalized the manuscript.

\section{ACKNOWLEDGMENTS}

The authors acknowledge Sophisticated Analytical Instrumentation Facility, Panjab University (PU), Chandigarh, India, for supporting this research.

alkaline protease from Penicillium chrysogenium strain X5 used as excellent bio-additive for textile processing. Int. J. Biol. Macromol. 119, 1002-1016. doi: 10.1016/j.ijbiomac.2018.07.194

Candiano, G., Bruschi, M., Musante, L., Santucci, L., Ghiggeri, G. M., Carnemolla, B., et al. (2004). Blue silver: a very sensitive colloidal Coomassie G-250 staining for proteome analysis. Electrophoresis 25, 1327-1333. doi: 10.1002/elps. 200305844

Cavello, I. A., Hours, R. A., and Cavalitto, S. F. (2013). Enzymatic hydrolysis of gelatin layers of X-ray films and release of silver particles using keratinolytic serine proteases from Purpureocillium lilacinum LPS\# 876. J. Microbiol. Biotechn. 23, 1133-1139. doi: 10.4014/jmb.1302.02038

Champasri, C., Phetlum, S., and Pornchoo, C. (2021). Diverse activities and biochemical properties of amylase and proteases from six freshwater fish species. Sci. Rep. 11, 1-11. doi: 10.1038/s41598-021-85258-7

Chen, X., Zhou, C., Xue, Y., Shi, J., and Ma, Y. (2018). Cloning, expression, and characterization of an alkaline protease, AprV, from Vibrio sp. DA1-1. Bioprocess. Biosyst. Eng. 41, 1437-1447. doi: 10.1007/s00449-018-1972-6

Dawid, W. (2000). Biology and global distribution of myxobacteria in soils. FEMS Microbiol. Rev. 24, 403-427. doi: 10.1016/S0168-6445(00)00032-2

Deng, A., Wu, J., Zhang, Y., Zhang, G., and Wen, T. (2010). Purification and characterization of a surfactant-stable high-alkaline protease from Bacillus sp. B001. Bioresour. Technol. 101, 7100-7106. doi: 10.1016/j.biortech.2010.03.130

Doddapaneni, K. K., Tatineni, R., Vellanki, R. N., Rachcha, S., Anabrolu, N., Narakuti, V., et al. (2009). Purification and characterization of a solvent and detergent-stable novel protease from Bacillus cereus. Microbiol. Res. 164, 383390. doi: 10.1016/j.micres.2007.04.005

Doukyu, N., and Ogino, H. (2010). Organic solvent-tolerant enzymes. Biochem. Eng. J. 48, 270-282. doi: 10.1016/j.bej.2009.09.009

Dumont, L., Verneuil, B., Wallach, J., and Julien, R. (1994). Purification and characterization of an alkaline elastase from Myxococcus xanthus. Eur. J. Biochem. 223, 775-782. doi: 10.1111/j.1432-1033.1994.tb19052.x

Garcia, R., Gemperlein, K., and Müller, R. (2014). Minicystis rosea gen. nov., Sp. nov., a polyunsaturated fatty acid-rich and steroid-producing soil myxobacterium. Int. J. Syst. Evol. Microbiol. 64, 3733-3742. doi: 10.1099/ijs.0. 068270-0

George, N., Chauhan, P. S., Kumar, V., Puri, N., and Gupta, N. (2014). Approach to ecofriendly leather: characterization and application of an alkaline protease for chemical free dehairing of skins and hides at pilot scale. J. Clean Prod. 79, 249-257. doi: 10.1016/j.jclepro.2014.05.046

Gnosspelius, G. (1978). Purification and properties of an extracellular protease from Myxococcus virescens. J. Bacteriol. 133, 17-25. doi: 10.1128/jb.133.1.1725.1978 
Finke, M. D. (2013). Complete nutrient content of four species of feeder insects. Zoo Biology 32, 27-36. doi: 10.1002/zoo.21012

Hamdi, M., Hammami, A., Hajji, S., Jridi, M., Nasri, M., and Nasri, R. (2017). Chitin extraction from blue crab (Portunus segnis) and shrimp (Penaeus kerathurus) shells using digestive alkaline proteases from P. segnis viscera. Int. J. Biol. Macromol. 101, 455-463. doi: 10.1016/j.ijbiomac.2017.02.103

Hammami, A., Fakhfakh, N., Abdelhedi, O., Nasri, M., and Bayoudh, A. (2018). Proteolytic and amylolytic enzymes from a newly isolated Bacillus mojavensis SA: characterization and applications as laundry detergent additive and in leather processing. Int. J. Biol. Macromol. 108, 56-68. doi: 10.1016/j.ijbiomac. 2017.11.148

Hammami, A., Hamdi, M., Abdelhedi, O., Jridi, M., Nasri, M., and Bayoudh, A. (2017). Surfactant- and oxidant-stable alkaline proteases from Bacillus invictae: characterization and potential applications in chitin extraction and as a detergent additive. Int. J. Biol. Macromol. 96, 272-281. doi: 10.1016/j.ijbiomac. 2016.12.035

Heussen, C., and Dowdle, E. B. (1980). Electrophoretic analysis of plasminogen activators in polyacrylamide gels containing sodium dodecyl sulfate and copolymerized substrates. Anal. Biochem. 102, 196-202. doi: 10.1016/00032697(80)90338-3

Ibrahim, A. S. S., Elbadawi, Y. B., El-Tayeb, M. A., Al-maary, K. S., Maany, D. A. F., Ibrahim, S. S. S., et al. (2019). Alkaline serine protease from the new halotolerant alkaliphilic Salipaludibacillus agaradhaerens strain AK-R: purification and properties. 3 Biotech 9:391. doi: 10.1007/s13205-019-1928-9

Iizuka, T., Jojima, Y., Hayakawa, A., Fujii, T., Yamanaka, S., and Fudou, R. (2013). Pseudenhygromyxa salsuginis gen. nov., sp. nov., a myxobacterium isolated from an estuarine marsh. Int. J. Syst. Evol. Microbiol. 63, 1360-1369. doi: 10. 1099/ijs.0.040501-0

Jain, D., Pancha, I., Mishra, S. K., Shrivastav, A., and Mishra, S. (2012). Purification and characterization of haloalkaline thermoactive, solvent stable and SDSinduced protease from Bacillus sp.: a potential additive for laundry detergents. Bioresour. Technol. 115, 228-236. doi: 10.1016/j.biortech.2011.10.081

Kocadag Kocazorbaz, E., and Zihnioglu, F. (2017). Purification, characterization and the use of recombinant prolyl oligopeptidase from Myxococcus xanthus for gluten hydrolysis. Protein Expr. Purif. 129, 101-107. doi: 10.1016/j.pep.2016.09. 016

Kumar, S., Yadav, A. K., Chambel, P., and Kaur, R. (2017). Molecular and functional characterization of myxobacteria isolated from soil in India. 3 Biotech 7:112. doi: 10.1007/s13205-017-0722-9

Laemmli, U. K. (1970). Cleavage of structural proteins during the assembly of the head of bacteriophage T4. Nature 227, 680-685. doi: 10.1038/227680a0

Li, J., Jiang, L., Cao, X., Wu, Y., Lu, F., Liu, F., et al. (2021). Improving the activity and stability of Bacillus clausii alkaline protease using directed evolution and molecular dynamics simulation. Enzyme Microb. Technol. 147, 109787.

Liu, S., Sun, J., Yu, L., Zhang, C., Bi, J., Zhu, F., and Yang, Q. (2012). Extraction and characterization of chitin from the beetle holotrichia parallela motschulsky. Molecules 17, 4604-4611. doi: 10.3390/molecules 17044604

Maase, F. W. J. L., and van Tilburg, R. (1983). The benefit of detergent enzymes under changing washing conditions. J. Am. Oil Chem. Soc. 60, 1672-1675. doi: $10.1007 / \mathrm{BF} 02662431$

Masui, A., Yasuda, M., Fujiwara, N., and Ishikawa, H. (2004). Enzymatic hydrolysis of gelatin layers on used lith film using thermostable alkaline protease for recovery of silver and PET film. Biotechnol. Prog. 20, 1267-1269. doi: 10.1021/ bp030058s

Matkawala, F., Nighojkar, S., Kumar, A., and Nighojkar, A. (2019). Biocatalysis and Agricultural Biotechnology Enhanced production of alkaline protease by Neocosmospora sp. N1 using custard apple seed powder as inducer and its application for stain removal and dehairing. Biocatal. Agric. Biotechnol. 21:101310. doi: 10.1016/j.bcab.2019.101310

Meyers, S. P., and Ahearn, D. G. (1977). Extracellular proteolysis by Candida Lipolytica. Mycologia 69, 646-651. doi: 10.1080/00275514.1977.12020106

Mhamdi, S., Ktari, N., Hajji, S., Nasri, M., and Sellami, K. A. (2017). Alkaline proteases from a newly isolated Micromonospora chaiyaphumensis S103: characterization and application as a detergent additive and for chitin extraction from shrimp shell waste. Int. J. Biol. Macromol. 94, 415-422. doi: 10.1016/j. ijbiomac.2016.10.036
Mothe, T., and Sultanpuram, V. R. (2016). Production, purification and characterization of a thermotolerant alkaline serine protease from a novel species Bacillus caseinilyticus. 3 Biotech 6:53. doi: 10.1007/s13205-016-0377-y

Muñoz-Dorado, J., Marcos-Torres, F. J., García-Bravo, E., Moraleda-Muñoz, A., and Pérez, J. (2016). Myxobacteria: moving, killing, feeding, and surviving together. Front. Microbiol. 7:781. doi: 10.3389/fmicb.2016.00781

Murthy, L. N., Phadke, G. G., Unnikrishnan, P., Annamalai, J., Joshy, C. G., Zynudheen, A. A., et al. (2018). Valorization of fish viscera for crude proteases production and its use in bioactive protein hydrolysate preparation. Waste Biomass Valorization 9, 1735-1746. doi: 10.1007/s12649-017-9962-5

Niyonzima, F. N., and More, S. (2015). Detergent-compatible proteases: microbial production, properties, and stain removal analysis. Prep. Biochem. Biotechnol. 45, 233-258. doi: 10.1080/10826068.2014.907183

Paul, T., Das, A., Mandal, A., Halder, S. K., Jana, A., Maity, C., et al. (2014). An efficient cloth cleaning properties of a crude keratinase combined with detergent: towards industrial viewpoint. J. Clean Prod. 66, 672-684. doi: 10. 1016/j.jclepro.2013.10.054

Petit, F., and Guespin-Michel, J. F. (1992). Production of an extracellular milkclotting activity during development in Myxococcus xanthus. J. Bacteriol. 174, 5136-5140. doi: 10.1128/jb.174.15.5136-5140.1992

Poza, M., Sieiro, C., Carreira, L., Barros-Velázquez, J., and Villa, T. G. (2003). Production and characterization of the milk-clotting protease of Myxococcus xanthus strain 422. J. Ind. Microbiol. Biotechnol. 30, 691-698. doi: 10.1007/ s10295-003-0100-y

Ramkumar, A., Sivakumar, N., Gujarathi, A. M., and Victor, R. (2018). Production of thermotolerant, detergent stable alkaline protease using the gut waste of Sardinella longiceps as a substrate: optimization and characterization. Sci. Rep. 8:12442. doi: 10.1038/s41598-018-30155-9

Rao, M. B., Tanksale, A. M., and Ghatge, M. S. (1998). Molecular and biotechnological aspects of microbial proteases. Microbiol. Mol. Biol. Rev. 62, 597-635. doi: 10.1128/MMBR.62.3.597-635.1998

Rao, M. S., Munoz, J. and Stevens, W. F. (2000). Critical factors in chitin production by fermentation of shrimp biowaste. Appl. Microbiol. Biotechnol. 54, 808-813. doi: $10.1007 /$ s002530000449

Rawlings, N. D., Barrett, A. J., Thomas, P. D., Huang, X., Bateman, A., and Finn, R. D. (2018). The MEROPS database of proteolytic enzymes, their substrates and inhibitors in 2017 and a comparison with peptidases in the PANTHER database. Nucleic Acids Res. 46, D624-D632. doi: 10.1093/nar/ gkx1134

Razzaq, A., Shamsi, S., Ali, A., Ali, Q., Sajjad, M., Malik, A., et al. (2019). Microbial proteases applications. Front. Bioeng. Biotechnol. 7:110. doi: 10.3389/fbioe.2019. 00110

Reddy, M. R., Reddy, K. S., Chouhan, Y. R., Bee, H., and Reddy, G. (2017). Effective feather degradation and keratinase production by Bacillus pumilus GRK for its application as bio-detergent additive. Bioresour. Technol. 243, 254-263. doi: 10.1016/j.biortech.2017.06.067

Reichenbach, H., and Dworkin, M. (1992). "The myxobacteria," in The Prokaryotes, eds A. Balows, H. G. Truper, M. Dworkin, W. Harder, and K. H. Scheifer (New York, NY: Springer), doi: 10.1007/978-1-4757-2191-1_26

Shan, L., Marti, T., Sollid, L. M., Gray, G. M., and Khosla, C. (2004). Comparative biochemical analysis of three bacterial prolyl endopeptidases: implications for coeliac sprue. Biochem. J. 383, 311-318. doi: 10.1042/BJ200 40907

Shazly, A. B., Mu, H., Liu, Z., El-Aziz, M. A., Zeng, M., Qin, F., et al. (2019). Release of antioxidant peptides from buffalo and bovine caseins: influence of proteases on antioxidant capacities. Food Chem. 274, 261-267. doi: 10.1016/j.foodchem. 2018.08.137

Singh, A., Sharma, A., Bansal, S., and Sharma, P. (2018). Comparative interaction study of amylase and surfactants for potential detergent formulation. J. Mol. Liq. 261, 397-401. doi: 10.1016/j.molliq.2018.04.047

Singh, S., and Bajaj, B. K. (2017). Potential application spectrum of microbial proteases for clean and green industrial production. Energy Ecol. Environ. 2, 370-386. doi: 10.1007/s40974-017-0076-5

Sivasubramanian, S., Murali Manohar, B., Rajaram, A., and Puvanakrishnan, R. (2008). Ecofriendly lime and sulfide free enzymatic dehairing of skins and hides using a bacterial alkaline protease. Chemosphere 70, 1015-1024. doi: 10.1016/j. chemosphere.2007.09.036 
Suginta, W., Sirimontree, P., Sritho, N., Ohnuma, T., and Fukamizo, T. (2016). The chitin-binding domain of a GH-18 chitinase from Vibrio harveyi is crucial for chitin-chitinase interactions. Int. J. Biol. Macromol. 93, 1111-1117. doi: 10.1016/j.ijbiomac.2016.09.066

Tamura, K., Stecher, G., Peterson, D., Filipski, A., and Kumar, S. (2013). MEGA6: molecular evolutionary genetics analysis version 6.0. Mol. Biol. Evol. 30, 27252729. doi: 10.1093/molbev/mst197

Tatineni, R., Doddapaneni, K. K., Potumarthi, R. C., Vellanki, R. N., Kandathil, M. T., Kolli, N., et al. (2008). Purification and characterization of an alkaline keratinase from Streptomyces sp. Bioresour. Technol. 99, 1596-1602. doi: 10. 1016/j.biortech.2007.04.019

Thanikaivelan, P., Rao, J. R., Nair, B. U., and Ramasami, T. (2004). Progress and recent trends in biotechnological methods for leather processing. Trends Biotechnol 22, 181-188. doi: 10.1016/j.tibtech.2004. 02.008

Thomas, N. N., Archana, V., Shibina, S., and Edwin, B. T. (2020). Isolation and characterization of a protease from Bacillus sp. Mater Today Proc. 41, 685-691. doi: 10.1016/j.matpr.2020.05.435

Tu, M., Liu, H., Zhang, R., Chen, H., Mao, F., Cheng, S., et al. (2018). Analysis and evaluation of the inhibitory mechanism of a novel angiotensin-I-converting enzyme inhibitory peptide derived from casein hydrolysate. J. Agric. Food Chem. 66, 4139-4144. doi: 10.1021/acs.jafc.8b 00732

Yang, S., Zhai, L., Huang, L., Meng, D., Li, J., Hao, Z., et al. (2020). Mining of alkaline proteases from Bacillus altitudinis W3 for desensitization of milk proteins: their heterologous expression, purification, and characterization. Int. J. Biol. Macromol. 153, 1220-1230. doi: 10.1016/j.ijbiomac.2019.10.252

Younes, I., Ghorbel-Bellaaj, O., Nasri, R., Chaabouni, M., Rinaudo, M., and Nasri, M. (2012). Chitin and chitosan preparation from shrimp shells using optimized enzymatic deproteinization. Process Biochem. 47, 2032-2039. doi: 10.1016/j. procbio.2012.07.017

Yu, P., Huang, X., Ren, Q., and Wang, X. (2019). Purification and characterization of a H2O2-tolerant alkaline protease from Bacillus sp. ZJ1502, a newly isolated strain from fermented bean curd. Food Chem. 274, 510-517. doi: 10.1016/j. foodchem.2018.09.013
Zhang, H., Jin, Y., Deng, Y., Wang, D., and Zhao, Y. (2012). Production of chitin from shrimp shell powders using Serratia marcescens B742 and Lactobacillus plantarum ATCC 8014 successive two-step fermentation. Carbohydr. Res. 362, 13-20. doi: 10.1016/j.carres.2012.09.011

Zhang, H., Li, H., Liu, H., Lang, D. A., Xu, H., and Zhu, H. (2019). The application of a halotolerant metalloprotease from marine bacterium Vibrio sp LA-05 in liquid detergent formulations. Int. Biodeterior. Biodegrad. 142, 18-25. doi: 10. 1016/j.ibiod.2019.04.006

Zhang, Q., Wang, L., Liu, S., and Li, Y. (2021). Establishment of successive cofermentation by Bacillus subtilis and Acetobacter pasteurianus for extracting chitin from shrimp shells. Carbohydr. Polym. 258:117720. doi: 10.1016/j. carbpol.2021.117720

Zhou, C., Qin, H., Chen, X., Zhang, Y., Xue, Y., and Ma, Y. (2018). A novel alkaline protease from alkaliphilic Idiomarina sp. C9-1 with potential application for eco-friendly enzymatic dehairing in the leather industry. Sci. Rep. 8:16467. doi: 10.1038/s41598-018-34416-5

Zhouxiang, H., Jianying, W., Ma, Z., and Jifan, H. (2008). A method to recover silver from waste X-ray films with spent fixing bath. Hydrometallurgy 92, 148-151. doi: 10.1016/j.hydromet.2008.02.006

Conflict of Interest: The authors declare that the research was conducted in the absence of any commercial or financial relationships that could be construed as a potential conflict of interest.

Publisher's Note: All claims expressed in this article are solely those of the authors and do not necessarily represent those of their affiliated organizations, or those of the publisher, the editors and the reviewers. Any product that may be evaluated in this article, or claim that may be made by its manufacturer, is not guaranteed or endorsed by the publisher.

Copyright (c) 2021 Sharma, Kumar, Kaur and Kaur. This is an open-access article distributed under the terms of the Creative Commons Attribution License (CC BY). The use, distribution or reproduction in other forums is permitted, provided the original author(s) and the copyright owner(s) are credited and that the original publication in this journal is cited, in accordance with accepted academic practice. No use, distribution or reproduction is permitted which does not comply with these terms. 